\title{
Biological applications of macrocyclic Schiff base ligands and their metal complexes: a survey of the literature (2005-2019)
}

\author{
Reza Golbedaghi, ${ }^{a, b, *}$ Andreia M. Tabanez ${ }^{b}$ and Rui Fausto ${ }^{b}$ \\ ${ }^{a}$ Chemistry Department, Payame Noor University, 19395-4697, Tehran, Iran. \\ ${ }^{b}$ CQC, Department of Chemistry, University of Coimbra, P-3004-535 Coimbra, Portugal.
}

\begin{abstract}
This article aims to provide a survey of biological applications of Schiff base macrocycles and their metal complexes, with emphasis given to the synthesis of the compounds and to their uses as antibacterial and antifungal agents. The literature on the subject, published during the 2005-2019 period, is shortly reviewed. This is an informed report collecting information on the addressed topic in a concise systematic way, and can be expected to be useful as a fast literature catalogue for researchers working on this and related domains.
\end{abstract}

Keywords: Macrocyclic Schiff base ligands and their metal complexes; biological applications; literature survey (2005-2019).

* Corresponding author e mail: golbedaghi82@gmail.com 


\section{Introduction}

\subsection{Polyamines}

Di- and polyamines are relatively simple organic substances that have two or more than two amino groups, respectively, in their structure. Low molecular weight linear di- and polyamines are found in all forms of life, including the human body, and they are involved in key biological processes in animals and plants [1-6]. The most abundant members of this type of compounds in living systems include the diamine putrescine (1,4-diaminobutane), the triamine spermidine ( $N$-(3aminopropyl)-1,4-butanediamine), and the tetraamine spermine ( $N, N^{\prime}$-bis(3-aminopropyl)-1,4butanediamine). Other di- or polyamines occurring in lower concentration in living organisms comprise trimethylenediamine (1,3-diaminopropane), cadaverine (1,5-diaminopentane), homospermidine ( $N$-(4-aminobutyl)-1,4-butanediamine), and norspermine $\quad\left(N, N^{\prime}\right.$-bis(3aminopropyl)-1,3-propanediamine), but the list includes a few dozens of compounds $[7,8]$.

The first biogenic amine discovered was spermine, that was identified in the human semen by van Leeuwenhoek, in 1677, in the form of phosphate [9]. Interestingly, the correct structure of the compound was only determined in $1926[10,11]$. Spermidine was also discovered and isolated from semen, in the beginning of the $20^{\text {th }}$ century [2]. Putrescine and cadaverine are likewise present in the semen, but they were discovered together, by the end of the $19^{\text {th }}$ century, in decaying matter, where they appear as result of the breakdown of amino acids [12-14]. These compounds may occur in both eukaryote (e.g., animals, plants, algae) and prokaryote (bacteria) cells [1-14].

The usual amount of di- and polyamines present inside the cells of living systems is at the millimol level $[15,16]$. However, the concentration of free amines is small and maintained within a very narrow range ( $7-10 \%$ of the total amount) because the decrease in their concentration inhibits cell proliferation while excess is toxic $[15,16]$. Indeed, most of the di- and polyamines in 
the cells are bound to different polyanionic molecules, especially nucleic acids, but also proteins and phospholipids [13-18].

It has been noticed that an increase in the concentration of polyamines may be associated with rapidly proliferating cancer cells (in particular in the case of breast, colon, lung, prostate and skin tumors) $[19,20]$, and this has been used as basis for diagnosing cancer and monitoring progresses during cancer treatment $[6,19,20-22]$. In fact, the interaction of polyamines with nucleic acids and other biological molecules, in terms of their association with cancer, has become the focus of intensive research [1,19-24].

Another relevant use of di- and polyamines is in the synthesis of Schiff base compounds, which can then receive applications in coordination chemistry. Indeed, complexation of Schiff base ligands (in particular of macrocyclic Schiff base derivatives) with metal ions has been shown to give rise to a considerable number of chemical systems exhibiting unique properties for application in several domains, like catalysis, materials sciences and medicine, for example $[25,26]$. This fact has been giving increased importance to the investigation on this particular type of compounds.

\subsection{Schiff base ligands}

Schiff bases are compounds with the general formula $R R^{\prime} C=N R^{\prime \prime}\left(R^{\prime \prime} \neq H\right)$, and can be considered a sub-class of imines $[27,28]$. Depending on its structure, a Schiff base can be either a secondary aldimine (when $\mathrm{R}$ or $\mathrm{R}^{\prime}$ is an $\mathrm{H}$ atom) or a secondary ketamine (when both $\mathrm{R}$ and $\mathrm{R}$ ' are different from $\mathrm{H}$ ). Their general designation (Schiff base) originates from Hugo Schiff, who first discover this type of compounds [29]. A number of other specific usual names exist for Schiff bases having particular structural elements. For example, a Schiff base derived from an aniline (where R" is a 
phenyl or a substituted phenyl group) can be called an anil, while bis-Schiff base compounds are frequently designated as Salen-type compounds.

Schiff bases can be synthesized from an aliphatic or aromatic amine and a carbonyl compound by nucleophilic addition forming a hemiaminal, followed by dehydration to generate the imine.

\section{(Scheme 1).}
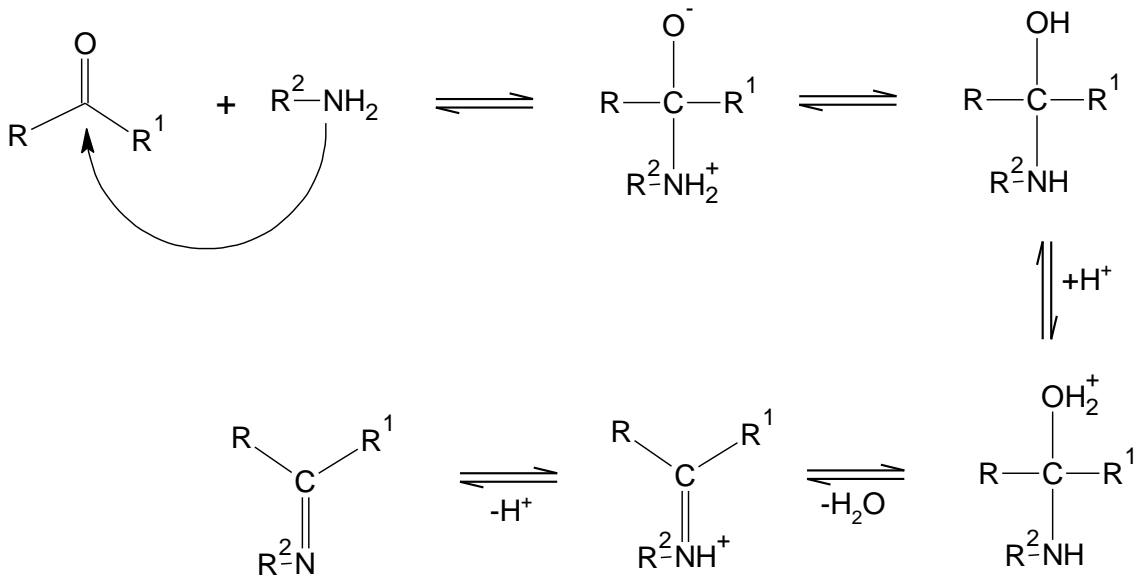

Scheme 1 - Synthesis of a Schiff base from condensation of a carbonyl and an amine precursor.

The literature on Schiff bases is extensive and it is not purpose of this article to address this general topic. In here, we will focus on a specific type of Schiff bases, the ones designated currently by macrocyclic Schiff bases, which are the members of this family of compounds bearing at least one large (7 membered or larger) ring. An example of a naturally occurring macrocyclic Schiff base derivative is corrin, which is the parent macrocycle related to the substituted derivative found in vitamin $\mathrm{B}_{12}$ (cobalamine), but the majority of this type of compounds are produced in the laboratory.

Considerable effort has been made in the last two decades for developing metal-free methods for furnishing macrocycles starting from dicarbonyl compounds and diamines (Scheme 2) in addition to standard metal-templated protocols [30,31]. A large variety of [1+1] and [2+2]- 
(macrocyclic) ligands has been synthesized in order to ascertain correctly the role of the different coordinating atoms and of their relative position on the structures resulting from coordination of these ligands to metal ions [30-41]. These studies also aimed to understand the factors that most contribute to determine the number and size of the chelating rings formed upon complexation of Schiff base macrocyclic ligands, as well as the effect of the flexibility and shape of the coordinating moiety on binding [31,42-45]. Progress on the chemistry for synthesis of these type of Schiff bases has allowed, for example, the preparation of macrobicyclic ligands via a one-step multiple condensation reactions procedure [30,42-45].

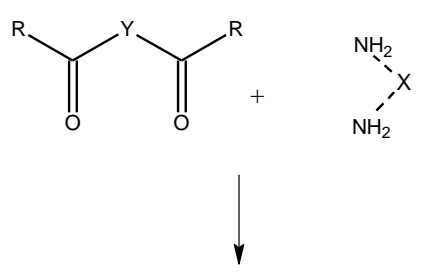<smiles>[2H]C(=O)N=C([2H])N=C([2H])N=C([2H])[3H]</smiles>

$[2+1]$

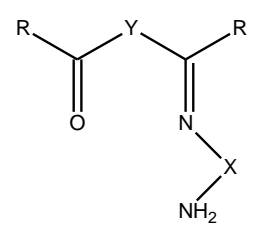

$[1+1]$

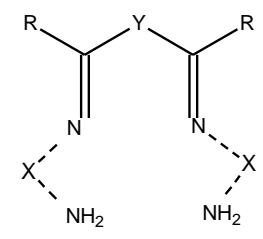

$[1+2]$

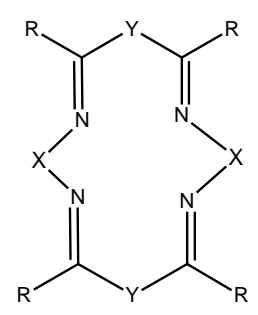

[2+2]-(Macrocycle)

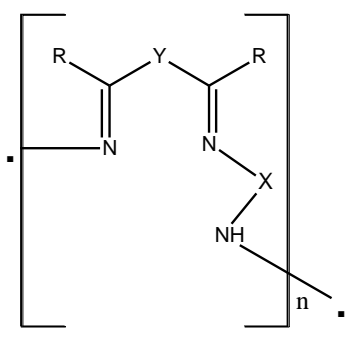

Oligomers

Scheme 2 - Main possible condensation products of dicarbonyl compounds with diamines in different proportions. The $\mathrm{R}$ groups may be distinct from each other and $\mathrm{X}$ and $\mathrm{Y}$ represent generic fragments (in general alkyl chains). 
The macrocyclic Schiff bases can also be reduced to the related polyamine derivatives, containing the same cyclic complexity, by reaction with an appropriate reducing agent [30-33]. Similarly, the related complexes can undergo reductive decomplexation reactions when treated with appropriate reductants, with the consequent formation of the corresponding polyamine derivatives [30-33]. These polyamine compounds are less sensitive to hydrolysis and more flexible than their imine analogous, what can be of interest for certain applications.

Introduction of specific functionalities at the periphery of the coordinating moiety has allowed the synthesis of macrocyclic systems capable of multi-recognition, and that may be used, for example, in specific separation [46-48], transport processes across membranes [49,50], or activation and catalysis in ecocompatible solvents [51]. In these areas, the presence in the molecules of pendant arms (two or more) attached to the proper positions of the macrocycle framework appears particularly interesting, since it allows for the generation of a pseudo-enclosed environment suitable for modeling of supramolecular molecule-receptor systems [52]. On the other hand, for macrocycles acting as receptors, the hole size represents an additional parameter which may greatly influence the ability to discriminate among the different species to be recognized.

Macrocyclic Schiff base derivatives are in general good chelating agents and prone to form different types of complexes with metal ions. In fact, one of the most popular methods for the synthesis of macrocyclic Schiff bases requires the active participation of a metal ion in the process, i.e., the metal-promoted one-step (template) condensation method [36-40]. In this synthetic procedure, a metal ion is used as template to induce orientation of the reacting groups of linear substrates in the required conformation for the ring to close [53]. In this way, one has direct access to macrocyclic Schiff base metal complexes, whose practical applications are, as already 
mentioned, relevant in many different domains $[14,17,33,52]$. In this article we will focus on their uses as bioactive systems, in particular as antibacterial and antifungal agents.

\subsection{Macrocyclic Schiff base metal complexes}

The majority of therapeutic drugs are organic compounds and, because of this, less attention has been given in this field to inorganic and coordination compounds. Nevertheless, the number of inorganic and coordination compounds shown to exhibit beneficial bioactive properties has been growing considerably during the last decades. They have been noticed to be particularly effective in cancer therapy, as a result of their ability to specifically interact with DNA [1,6,19-24,54]. The prototype compound is cisplatin [cis-diaminedichloroplatinum(II)], which was approved as a chemotherapeutic drug for use in testicular and ovarian cancers by the U.S. Food and Drug Administration (FDA) in 1978 [55-57], and in Europe one year later [58]. Interestingly, despite the fact that thousands of cisplatin analogues have been synthesized since then, and tested as potential anticancer drugs, only two of them, carboplatin and oxaliplatin, have been used in the clinical treatment of neoplasic diseases, while the rest have remained inactive [54,59-64].

Being common ligands in coordination chemistry, Schiff bases have been used extensively in this field, giving rise to a plethora of different types of complexes. Their coordination ability results mainly from the $\pi$-acceptor properties of their constituting imine nitrogen atom. Accordingly, the coordination versatility of Schiff bases strongly increases when the ligand bears several imine groups, which may act as multiple coordination sites. Procedures have been developed successfully for preparation of mono-, di- or polymacrocycles, catenands, compartmental ligands and calixarenes based on Schiff bases [65]. 
An interesting observation is that complexation with a metal often improves the stability of the Schiff base ligand, while the majority of macrocyclic complexes have also been noticed to be both kinetically and thermodynamically more stable than the analogous compounds with non-cyclic ligands [66]. These facts have contributed to stimulate research on this type of compounds, which in turn has allowed elucidating aspects of the reactivity of Schiff base coordination compounds that would not be possible to investigate using the less stable analogous complexes of non-cyclic ligands. The interest in exploring metal ion complexes with macrocyclic Schiff base type ligands has received strong stimulus also owing to the recognition of the role played by this kind of structures in metalloproteins [65], and a broad variety of Schiff base macrocycles have been used for metal-biosites modeling of cationic, anionic or neutral receptors [30]. In addition, the progress on synthetic macrocyclic chemistry has also resulted in an increased understanding of the properties and function of naturally occurring biological macrocycles and their complexes [52,67].

Among the general type of systems considered in this review, those formed by functionally substituted macrocyclic Schiff bases ligands bearing additional donor groups are of particular interest. Such ligands represent one of the most important classes of heteropolydentate ligands capable of forming not only mononuclear complexes of different types with transition and/or nontransition metal ions, but also diverse bi- and polynuclear complexes with potential for application in several areas. The progressive availability of larger and more multifarious ligands exhibiting such structural characteristics has been facilitating also the design of macrocyclic Schiff base metal complexes with specific properties resulting from the simultaneous presence of metal ions in close proximity within the same coordinating moiety. For example, using compartmental ligands, binuclear complexes have been synthesized where the two metal centers, if paramagnetic, interact with each other through the bridging donor atoms of the ligands in a ferromagnetic or 
antiferromagnetic way; by introducing modifications in the ligands, one can adjust the distance between the two chambers and/or the paramagnetic centers as well as the chemical environment around them, thus allowing for the modulation of the magnetic interactions in order to achieve the desired materials' magnetic properties [66].

These types of complexes can be obtained by self-condensation of suitable formyl- or ketoprecursors and primary (poly)amines followed by coordination to the metal center via reaction with an appropriate metal salt $[30,66]$. Alternatively, they can be obtained in a single step by the already mentioned metal-template procedure [36-40,53]. In some cases, the initially synthesized complexes can be converted in other species through transmetalation reactions, leading to species otherwise not accessible to synthesis [66]. Template and transmetalation reactions quite often give rise to the desired complexes in high-yield and in a satisfactory purity grade.

As shown in the next section, the potential biomedical applications of macrocyclic Schiff bases and of their metal complexes as antimicrobial agents are very relevant, and some drugs based on this type of pharmacophore are indeed already on the market or in advanced phases of clinical trials. Mimopezil \{IUPAC name: (5R,9R,E)-5-(((E)-5-chloro-2-hydroxy-3-methoxybenzylidene) amino)-11-ethylidene-7-methyl-5,6,9,10-tetrahydro-5,9-methanocycloocta[b]pyridin-2(1H)-one\}, for example, is an acetylcholinesterase (AChE) inhibitor that has demonstrated potential use in the treatment of Alzheimer's disease [68], while the drug known by dBET57 \{IUPAC name: 2-((S)4-(4-chlorophenyl)-2,3,9-trimethyl-6H-thieno[3,2-f][1,2,4]triazolo[4,3-a][1,4]diazepin-6-yl)-N(2-((2-(2,6-dioxopiperidin-3-yl)-1,3-dioxoisoindolin-4-yl)amino)ethyl)acetamide $\}$ is a cancer PROTAC (proteolysis-targeting chimeras) type active agent [69]. Nevertheless, in spite of all accumulated favorable data, and the large list of publications stressing the potential of this type of compounds as medicines, the practical use of macrocyclic compounds in general as drugs is yet 
rather limited. Indeed, there is still a considerable resistance to the acceptance of macrocycles as pharmaceutical agents mostly because they did not fit the usual structural paradigm followed by the industry: small heterocyclic molecules with a reduced number of functional groups that most of times conformed to the Lipinski's rule of five [70]. Also, the synthetic challenge for macrocyclic structures is just recently been partially overcome and time is still required to fulfil the necessities of the library formats needed for the high throughput screening efforts essential to the majority of contemporary drug discovery programs. These facts give additional relevance to publications gathering together the most prominent recent results on the bioactivity of macrocyclic compounds (as those considered in this article), which appear as a privileged way to stimulate further fundamental research in this field and, in particular, market-targeted research by the specialized R\&D laboratories of the pharmaceutical companies.

\section{Literature survey (highlights 2005-2019)}

In this section, the most relevant literature on biological applications of macrocyclic Schiff base ligands and their metal complexes appearing during the period 2005-2019 is reviewed in brief. The data have been arranged in the format of a table (Table 1), where the most relevant results and the systems investigated in the surveyed studies are concisely described. To facilitate the search for a specific chemical system, for each article mentioned in the Table an illustration is provided, which shows the schematic structure of a representative compound or type of compounds addressed in the cited publication. The articles are organized by year of publication instead of by subject. Though the alternative possibility has also some advantages, the presentation of the articles by chronological order permits to follow in an easier way the progress over the time on a given matter and, more importantly, to interconnect this progress with developments taking place on related 
subjects. On the whole, 84 articles (besides those cited in the introduction) dealing with biological applications (in many cases better designated as biological potential applications) of macrocyclic Schiff base ligands and their metal complexes are described in this review, in particular those related to their ability to act as antibacterial or/and antifungal agents. This is an informed report gathering information on this topic in a concise systematic way, and will certainly be of great value for the researchers working on this and related domains. 
Table 1. Biological applications of macrocyclic Schiff base ligands and their metal complexes: literature highlights 2005-2019.

\begin{tabular}{|c|c|c|c|}
\hline Authors & Summary & Illustrative studied compounds & Refs. \\
\hline $\begin{array}{l}\text { J. Gao, } \\
\text { F.R.Woolley, } \\
\text { R.A. Zingaro }\end{array}$ & $\begin{array}{l}\text { The first } \partial \text {-conjugated macrocyclic diimine and triaza } \\
\text { DNA-binding intercalators and their Pt(II) conjugates } \\
\text { have been synthesized by direct Schiff base } \\
\text { cyclocondensation. This paper describes a new class } \\
\text { of platinum-based antitumorals. }\end{array}$ & & {$[71]$} \\
\hline $\begin{array}{l}\text { B.H. Mruthyunjayaswamy, } \\
\text { Y.J. Omkar, } \\
\text { B. Ijare, } \\
\text { S.G. Patil, } \\
\text { S.M. Kudari }\end{array}$ & $\begin{array}{l}\text { A series of di- and tetra-nuclear complexes based on } \\
\text { two new macrocylic phenoxo-bridged ligands were } \\
\text { reported. The compounds were synthesized through } \\
\text { the template method by using the precursors } \\
2,6 \text {-diformyl-4-methylphenol, succinoyldihydrazide/ } \\
\text { sebacoyldihydrazide and their respective metal } \\
\text { chlorides. The } \mathrm{Cu}(\mathrm{II}), \mathrm{Co}(\mathrm{II}) \text { and } \mathrm{Zn}(\mathrm{II}) \text { complexes of } \\
\text { both the ligands have shown good antifungal activity } \\
\text { against } A \text {. niger and } F \text {. oxysporum and medium to } \\
\text { weak antibacterial activity against E. coli and } S \text {. } \\
\text { aureus. }\end{array}$ & & {$[72]$} \\
\hline $\begin{array}{l}\text { H.I. Ugras, } \\
\text { I. Basaran, } \\
\text { T. Kilic, } \\
\text { U. Cakir }\end{array}$ & $\begin{array}{l}\text { A new macrocyclic Schiff base has been prepared by } \\
\text { condensation of triethylene glycol diamine with } \\
\text { terephtalaldehyde. The synthesized ligand has been } \\
\text { shown to possess high activity against the studied } \\
\text { microorganisms (E. coli, S. epidermidis, B. subtilis, } S \text {. } \\
\text { aureus, S. Typhimirum, K. pneumonia, P. aeruginosa } \\
\text { and E. fecalis bacterial strains and the C. albicans } \\
\text { fungi). }\end{array}$ & & [73] \\
\hline $\begin{array}{l}\text { N. Nishat, } \\
\text { M.M. Haq, } \\
\text { T. Ahamad, } \\
\text { V. Kumar }\end{array}$ & $\begin{array}{l}\text { A new macrocycle, 1,16-diaza-7,10-diamino-6,11- } \\
\text { dioxo-1,17-bis[20-hydroxy-50-aminobenzyl] pipe- } \\
\text { razine-4,12-cyclododecadiene, has been synthesized } \\
\text { by a multistep process. The related complexes (with } \\
\mathrm{M}=\mathrm{Mn}(\mathrm{II}), \mathrm{Co}(\mathrm{II}), \mathrm{Ni}(\mathrm{II}), \mathrm{Cu}(\mathrm{II}) \text { or } \mathrm{Zn}(\mathrm{II}) \text { ) show } \\
\text { significant inhibitory activity against bacteria (B. } \\
\text { subtilis, B. megaterium, S. aureus, E. coli, P. } \\
\text { aeruginosa and } S . \text { boydii) and fungi (C. albicans, } \\
\text { Trichophyton sp., A. flavus, Fucerium sp., Mucor sp. } \\
\text { and Penicillium sp.). }\end{array}$ & & [74] \\
\hline $\begin{array}{l}\text { P.M. Reddy, } \\
\text { A.V.S.S. Prasad, } \\
\text { K. Shanker, } \\
\text { V. Ravinder }\end{array}$ & $\begin{array}{l}\text { Ten novel macrocyclic } \mathrm{Co}(\mathrm{II}) \text { compounds have been } \\
\text { synthesized by treating four } \mathrm{N}_{4} \text { and six } \mathrm{N}_{2} \mathrm{O}_{2} \text { donor } \\
\text { macrocycles with cobalt chloride in methanol. All of } \\
\text { them along with existing antibacterial drugs were } \\
\text { screened for antibacterial activity against Gram } \\
\text { positive and Gram negative bacteria. All these } \\
\text { compounds were found to be more active when } \\
\text { compared to streptomycin and ampicillin. }\end{array}$ & & [75] \\
\hline & & $\mathrm{X}=\mathrm{alkyl}$, aryl or $\mathrm{N}$-containing heterocyclic substituents & \\
\hline
\end{tabular}




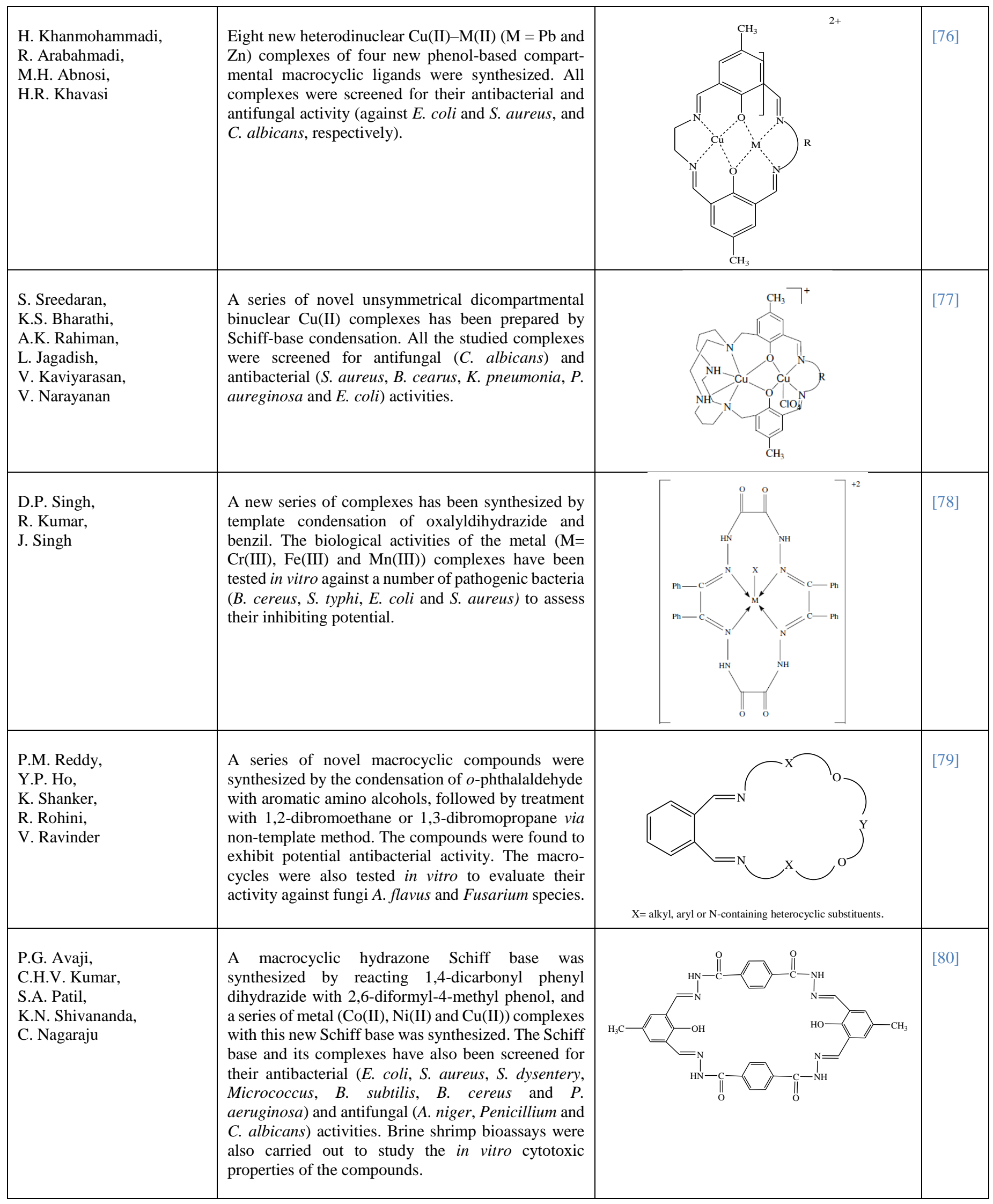




\begin{tabular}{|c|c|c|c|}
\hline $\begin{array}{l}\text { D.P. Singh, } \\
\text { R. Kumar, } \\
\text { J. Singh }\end{array}$ & $\begin{array}{l}\text { A new series of complexes was synthesized by } \\
\text { template condensation of oxalyldihydrazide and } \\
\text { glyoxal in methanolic medium in the presence of } \mathrm{M}= \\
\mathrm{Cr}(\mathrm{III}), \mathrm{Mn}(\mathrm{III}) \text { and } \mathrm{Fe}(\mathrm{III}) \text { salts. The biological } \\
\text { activities of the metal complexes were tested in vitro } \\
\text { against a number of pathogenic bacteria (B. cereus, } S \text {. } \\
\text { typhi, E. coli and } S \text {. aureus), some of the complexes } \\
\text { exhibiting remarkable antibacterial activities. }\end{array}$ & & [81] \\
\hline $\begin{array}{l}\text { D.P. Singh, } \\
\text { K. Kumar, } \\
\text { S.S. Dhiman, } \\
\text { J. Sharma }\end{array}$ & $\begin{array}{l}\text { A novel series of complexes of the type } \\
{\left[\mathrm{M}\left(\mathrm{C}_{24} \mathrm{H}_{16} \mathrm{~N}_{4}\right) \mathrm{X}_{2}\right](\mathrm{M}=\mathrm{Co}(\mathrm{II}), \mathrm{Ni}(\mathrm{II}), \mathrm{Cu}(\mathrm{II}), \mathrm{Zn}(\mathrm{II})} \\
\left.\text { and } \mathrm{Cd}(\mathrm{II}) ; \mathrm{X}=\mathrm{Cl}^{-}, \mathrm{NO}_{3}^{-}, \mathrm{CH}_{3} \mathrm{COO}^{-}\right) \text {has been } \\
\text { synthesized by template condensation of } 1,8- \\
\text { diaminonaphthalene and glyoxal in the presence of } \\
\text { salts of the different metals, in methanolic medium. } \\
\text { These metal complexes were also tested for in vitro } \\
\text { antibacterial }(B \text {. subtilis, B. stearothermophilus, E. } \\
\text { coli and } P \text {. putida) and antifungal }(A . \text { flavus and } A \text {. } \\
\text { niger }) \text { activities to assess their inhibiting potential. }\end{array}$ & & [82] \\
\hline $\begin{array}{l}\text { K. Shanker, } \\
\text { P.M. Reddy, } \\
\text { R. Rohini, } \\
\text { Y.P. Ho, } \\
\text { V. Ravinder }\end{array}$ & $\begin{array}{l}\text { New macrocyclic Schiff base } \mathrm{Pd}(\mathrm{II}) \text { compounds were } \\
\text { synthesized by treating } \mathrm{N}_{4} \text { and } \mathrm{N}_{2} \mathrm{O}_{2} \text { coordinating } \\
\text { macrocycles with palladium chloride. The biological } \\
\text { activities of all the macrocycles and macrocyclic } \\
\mathrm{Pd}(\mathrm{II}) \text { compounds have been tested (B. subtilis, S. } \\
\text { aureus, E. coli and } K \text {. pneumonia). The compounds } \\
\text { were found to be more active than commercially } \\
\text { available antibacterial drugs like streptomycin and } \\
\text { ampicillin. }\end{array}$ & $\mathrm{X}=$ alkyl, aryl or $\mathrm{N}$-containing heterocyclic substituents. & [83] \\
\hline $\begin{array}{l}\text { S. Sreedaran, } \\
\text { K.S. Bharathi, } \\
\text { A.K. Rahiman, } \\
\text { R. Prabu, } \\
\text { R. Jegadeesh, } \\
\text { N. Raaman, } \\
\text { V. Narayanan }\end{array}$ & $\begin{array}{l}\text { A series of unsymmetrical dicompartmental binuclear } \\
\mathrm{Cu}(\mathrm{II}) \text { complexes has been prepared by Schiff base } \\
\text { condensation of 1,8-[bis(3-formyl-2-hydroxy-5-bro- } \\
\text { mo)benzyl]-1,4,8,11-tetraazacyclotetradecane with } \\
\text { aliphatic and aromatic diamines, Cu(II) perchlorate } \\
\text { and trimethylamine. All the complexes show good } \\
\text { antimicrobial and antifungal activities against E. coli, } \\
P \text {. aeruginosa, B. subtilis, K. Pneumonia and S. } \\
\text { aureus, and C. albicans, respectively. }\end{array}$ & & [84] \\
\hline $\begin{array}{l}\text { N. Raman, } \\
\text { S.J. Raja, } \\
\text { J. Joseph, } \\
\text { A. Sakthivel }\end{array}$ & $\begin{array}{l}\text { Macrocyclic complexes of } \mathrm{Cu}(\mathrm{II}), \mathrm{Ni}(\mathrm{II}), \mathrm{Co}(\mathrm{II}) \text { and } \\
\mathrm{Zn} \text { (II) of a tetradentate Schiff base ligand derived } \\
\text { from 3-benzalideneacetoacetanile and } N \text {-( } 2 \text {-amino- } \\
\text { ethyl) } 1,3 \text {-propanediamine were synthesized. The in } \\
\text { vitro biological testing of the compounds against } E \text {. } \\
\text { coli, S. aureus, S. typhi and K. pneumonia was } \\
\text { performed. It was also shown that the copper complex } \\
\text { prefers to bind within DNA in oxidation state II } \\
\text { instead of I. }\end{array}$ & & [85] \\
\hline
\end{tabular}




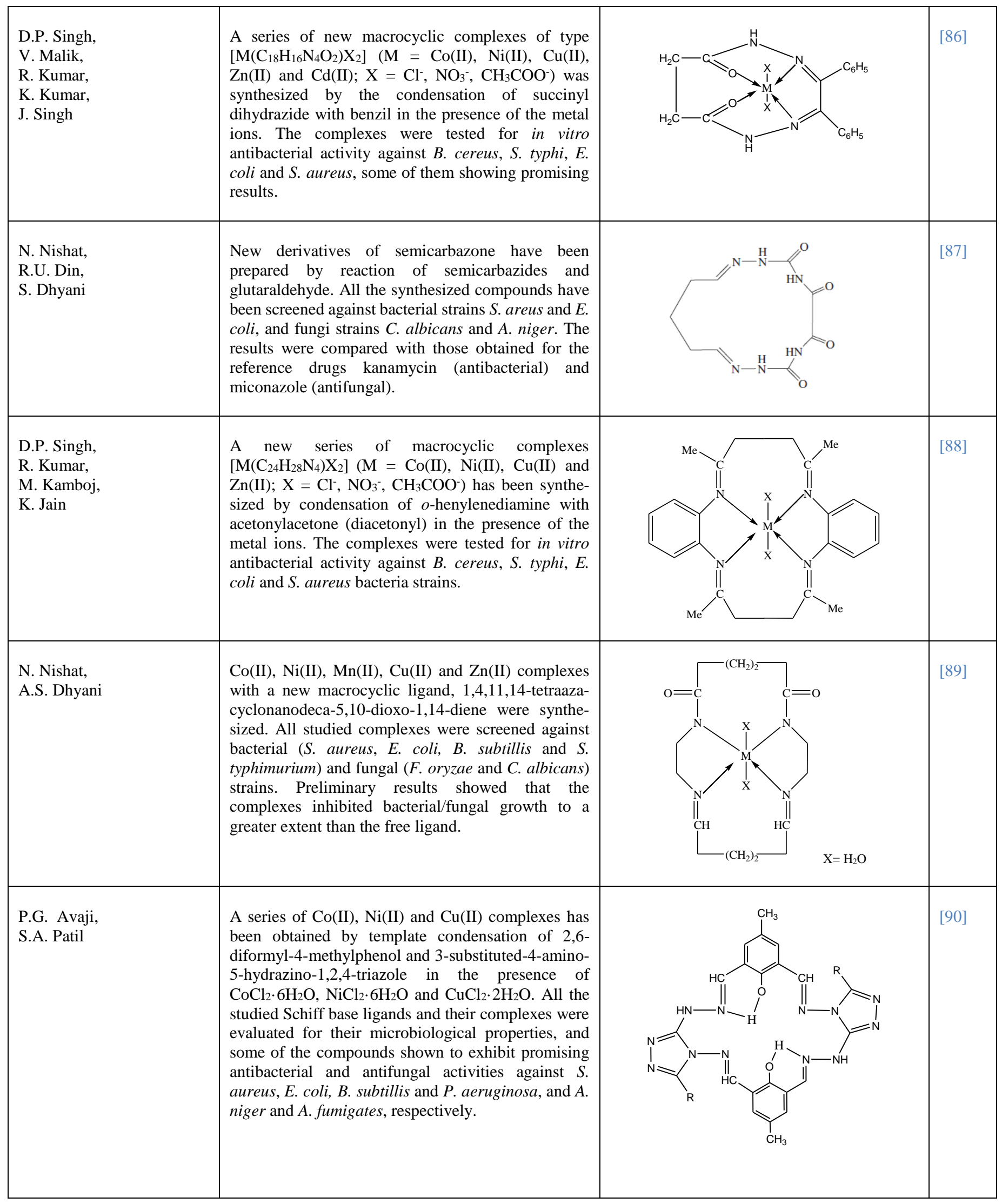




\begin{tabular}{|c|c|c|c|}
\hline $\begin{array}{l}\text { G.B. Bagihalli, } \\
\text { S.A. Patil }\end{array}$ & $\begin{array}{l}\text { A series of metal complexes has been synthesized } \\
\text { with newly-derived biologically active ligands. The } \\
\text { Schiff bases and their } \mathrm{Co}(\mathrm{II}), \mathrm{Ni}(\mathrm{II}), \mathrm{Cu}(\mathrm{II}) \text {, and } \\
\mathrm{Zn}(\mathrm{II}) \text { complexes have been screened for antibacterial } \\
\text { (E. coli, S. aureus, S. pyogenes, and P. aeruginosa), } \\
\text { and antifungal (A. niger, A. flavus, and } \\
\text { Cladosporium) activities by the minimum inhibitory } \\
\text { concentration method. DNA cleavage studies were } \\
\text { also carried out. }\end{array}$ & & [91] \\
\hline $\begin{array}{l}\text { S. Chandra, } \\
\text { S. Verma, } \\
\text { U. Dev, } \\
\text { N. Joshi }\end{array}$ & $\begin{array}{l}\text { A macrocyclic ligand, } 1,3,7,9 \text {-tetraaza-2,8-dithia- } \\
4,10 \text {-dimethyl-6,12-diphenylcyclododeca-4,6,10,12- } \\
\text { tetraene has been synthesized. Complexes of this } \\
\text { ligand with } \mathrm{Mn}(\mathrm{II}), \mathrm{Co}(\mathrm{II}), \mathrm{Ni}(\mathrm{II}) \text {, and } \mathrm{Cu}(\mathrm{II}) \text { was } \\
\text { been synthesized too. The ligand and its complexes } \\
\text { were screened in vitro against two pathogenic fungi } \\
(F \text {. moniliformae and } R \text {. solani) and bacteria ( } S \text {. } \\
\text { aureus and } P \text {. aeruginosa) to assess their growth } \\
\text { inhibiting potential. }\end{array}$ & $=\mathrm{s}$ & [92] \\
\hline $\begin{array}{l}\text { K. Shanker, } \\
\text { R. Rohini, } \\
\text { V. Ravinder, } \\
\text { P. M. Reddy, } \\
\text { Y.P. Ho }\end{array}$ & $\begin{array}{l}\text { A series of nitrogen and oxygen heterocyclic } \\
\text { macrocyclic ligands and their Ru(II) complexes were } \\
\text { synthesized. All the investigated ligands and the } \\
\text { Ru(II) complexes, along with existing antibacterial } \\
\text { drugs (streptomycin and ampicillin) were screened } \\
\text { for antibacterial activity against (B. subtilis, S. } \\
\text { aureus, E. coli and } K \text {. pneumonia) bacteria, the new } \\
\text { compounds being found to be more active than the } \\
\text { reference drugs. The representative macrocyclic } \\
\text { Schiff bases and their complexes were also tested in } \\
\text { vitro to evaluate their activity against fungi (A. flavus } \\
\text { and Fusarium) and compared with the amphotericin } \\
\text { and bavistin commercial drugs. }\end{array}$ & $\mathrm{X}=$ alkyl, aryl or $\mathrm{N}$-containing heterocyclic substituents. & [93] \\
\hline $\begin{array}{l}\text { A.P. Mishra, } \\
\text { R.K. Mishra, } \\
\text { S.P. Shrivastava }\end{array}$ & $\begin{array}{l}\text { Structural and antimicrobial studies of coordination } \\
\text { compounds of } \mathrm{M}=\mathrm{VO}(\mathrm{II}), \mathrm{Co}(\mathrm{II}), \mathrm{Ni}(\mathrm{II}) \text { and } \mathrm{Cu}(\mathrm{II}) \\
\text { with some Schiff bases derived from 2-amino-4- } \\
\text { chlorophenol were synthesized. The in vitro } \\
\text { biological screening effects of the investigated } \\
\text { compounds were tested against the bacteria E. coli, } S \text {. } \\
\text { aureus and } S . \text { fecalis, and the fungi A. niger, T. } \\
\text { polysporum and C. albicans. }\end{array}$ & & [94] \\
\hline $\begin{array}{l}\text { H. Khanmohammadi, } \\
\text { H. Keypour, } \\
\text { M. Salehi Fard, } \\
\text { M.H. Abnosi }\end{array}$ & $\begin{array}{l}\text { The synthesis and carachterization of four } \mathrm{Mg}(\mathrm{II}) \\
\text { complexes prepared via cyclocondensation of } 2,6- \\
\text { diformylpyridine and 2,6-diacetylpyridine with two } \\
\text { hexadentate hexaamines, in the presence of } \mathrm{Mg}(\mathrm{II}) \\
\text { ion, were reported. Their antibacterial and antifungal } \\
\text { properties against } E \text {. coli and } S \text {. aureus, and } C \text {. } \\
\text { albicans, respectively, were also described. }\end{array}$ & $\mathrm{R}=\mathrm{H}$ or $\mathrm{CH}_{3} ; \mathrm{X}=$ alkyl chain & [95] \\
\hline
\end{tabular}




\begin{tabular}{|c|c|c|c|}
\hline $\begin{array}{l}\text { D. Singh, } \\
\text { K. Kumar, } \\
\text { R. Kumar, } \\
\text { J. Singh }\end{array}$ & $\begin{array}{l}\text { A novel series of complexes of the type } \\
{\left[\mathrm{M}\left(\mathrm{C}_{28} \mathrm{H}_{24} \mathrm{~N}_{4}\right) \mathrm{X}_{2}\right], \text { where } \mathrm{M}=\mathrm{Co}(\mathrm{II}), \mathrm{Ni}(\mathrm{II}), \mathrm{Cu}(\mathrm{II}) \text {, }} \\
\mathrm{Zn}(\mathrm{II}) \text { and } \mathrm{Cd}(\mathrm{II}), \mathrm{X}=\mathrm{Cl}^{-}, \mathrm{NO}_{3}{ }^{-} \text {and } \mathrm{CH}_{3} \mathrm{COO}^{-} \text {, was } \\
\text { synthesized by template condensation of } 1,8- \\
\text { diaminonaphthalene and diacetyl in the presence of } \\
\text { divalent metal salts, in methanolic medium. The } \\
\text { macrocyclic complexes were tested for in vitro } \\
\text { antibacterial activity against some pathogenic } \\
\text { bacterial strains }(B . \text { cereus, } S \text {. typhi, E. coli and } S \text {. } \\
\text { aureus). The MIC values shown by the complexes } \\
\text { against were compared with the values shown by the } \\
\text { standard antibiotics linezolid and cefaclor. }\end{array}$ & & [96] \\
\hline $\begin{array}{l}\text { D.P. Singh, } \\
\text { K. Kumar, } \\
\text { S.S. Dhiman, } \\
\text { J. Sharma }\end{array}$ & $\begin{array}{l}\text { A new series of complexes of the type } \\
{\left[\mathrm{M}\left(\mathrm{C}_{24} \mathrm{H}_{16} \mathrm{~N}_{4}\right) \mathrm{X}\right] \mathrm{X}_{2} \text {, where } \mathrm{M}=\mathrm{Cr}(\mathrm{III}), \mathrm{Fe}(\mathrm{III}) \text { and }} \\
\mathrm{Mn}(\mathrm{III}) \text {, and } \mathrm{X}=\mathrm{Cl}^{-}, \mathrm{NO}_{3}^{-} \text {and } \mathrm{CH}_{3} \mathrm{COO}^{-} \text {, was } \\
\text { synthesized by template condensation of } 1,8- \\
\text { diaminonaphthalene and glyoxal in the presence of } \\
\text { metal salts, in methanolic medium. All the } \\
\text { synthesized metal complexes were tested for in vitro } \\
\text { antimicrobial activities against bacteria }(B \text {. subtilis, } B \text {. } \\
\text { stearothermophilus, E. coli, and } P . \text { putida }) \text { and fungi } \\
\text { (A. flavus and A. niger }) \text {. The results were compared } \\
\text { with those of antibiotics chloramphenicol and } \\
\text { streptomycin, and the antifungal drug cyclohexamide. }\end{array}$ & $x_{2}$ & [97] \\
\hline $\begin{array}{l}\text { S.A. Patil, } \\
\text { U.V. Kamble, } \\
\text { P. S. Badami }\end{array}$ & $\begin{array}{l}\text { A novel series of } \mathrm{N}_{2} \mathrm{O}_{2} \text { diazadioxa macrocyclic } \\
\text { complexes }\left[\mathrm{MLCl}_{2}\right](\mathrm{M}=\mathrm{Co}(\mathrm{II}), \mathrm{Ni}(\mathrm{II}) \text { and } \mathrm{Cu}(\mathrm{II})) \\
\text { was synthesized. The ligands were synthesized by the } \\
\text { condensation of 1,6-bis(2-formylphenyl) hexane and } \\
\text { 3-subtituted-4-amino-5-hydrazino-1,2,4-triazole. All } \\
\text { the studied complexes have been screened for their } \\
\text { antibacterial (E. coli, S. aureus, S. typhi, P. } \\
\text { aeruginosa) and antifungal (A. niger, A. flavus and } \\
\text { Cladosporium) activities by the MIC method. DNA } \\
\text { cleavage studies were also reported. }\end{array}$ & & [98] \\
\hline $\begin{array}{l}\text { U.V. Kamble, } \\
\text { S.A. Patil, } \\
\text { P.S. Badami }\end{array}$ & $\begin{array}{l}\text { A series of } 17 \text {-membered complexes }\left[\mathrm{MLCl}_{2}\right](\mathrm{M}= \\
\mathrm{Co}(\mathrm{II}), \mathrm{Ni}(\mathrm{II}) \text { and } \mathrm{Cu}(\mathrm{II})) \text { was prepared with newly } \\
\text { derived biologically active ligands. These ligands } \\
\text { were synthesized by condensation of } 3 \text {-subtituted-4- } \\
\text { amino-5-hydrazino- } 1,2,4 \text {-triazole with bis(phthal- } \\
\text { aldehyde) ethylene-diamine. The compounds were } \\
\text { screened for their antibacterial (E. coli, S. aureus, } S \text {. } \\
\text { typhi, } P \text {. aeruginosa) and antifungal }(A \text {. niger, A. } \\
\text { flavus and Cladosporium) activities. DNA cleavage } \\
\text { studies using these complexes were also reported. }\end{array}$ & & [99] \\
\hline $\begin{array}{l}\text { D.P. Singh, } \\
\text { K. Kumar }\end{array}$ & $\begin{array}{l}\text { The condensation of succinyldihydrazide with } \\
\text { diacetyl in the presence of the appropriate divalent } \\
\text { metal ions resulted in the formation of } \\
{\left[\mathrm{M}\left(\mathrm{C}_{8} \mathrm{H}_{12} \mathrm{~N}_{4} \mathrm{O}_{2}\right) \mathrm{X}_{2}\right] \text {, where } \mathrm{M}=\mathrm{Co}(\mathrm{II}), \mathrm{Ni}(\mathrm{II}), \mathrm{Cu}(\mathrm{II}) \text {, }} \\
\mathrm{Zn}\left(\mathrm{II} \text {, and } \mathrm{X}=\mathrm{Cl}^{-}, \mathrm{NO}_{3}^{-}, \mathrm{CH}_{3} \mathrm{COO}^{-} \text {. The complexes }\right. \\
\text { were tested for in vitro antibacterial activities }(S \text {. } \\
\text { aureus, B. subtilis, E. coli, and } P \text {. aeruginosa) and } \\
\text { compared with the standard antibiotic ciprofloxacin. }\end{array}$ & & [100] \\
\hline
\end{tabular}




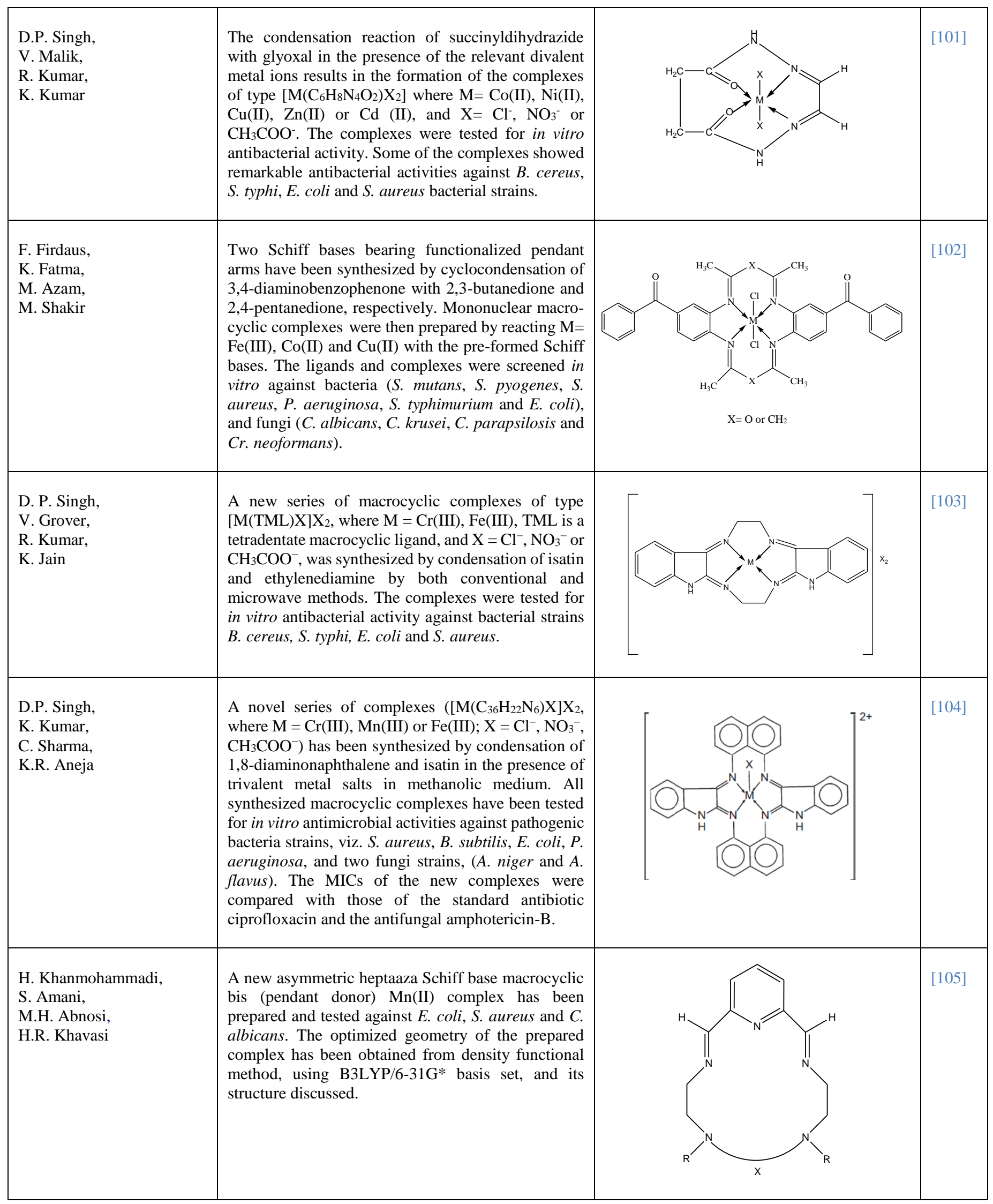




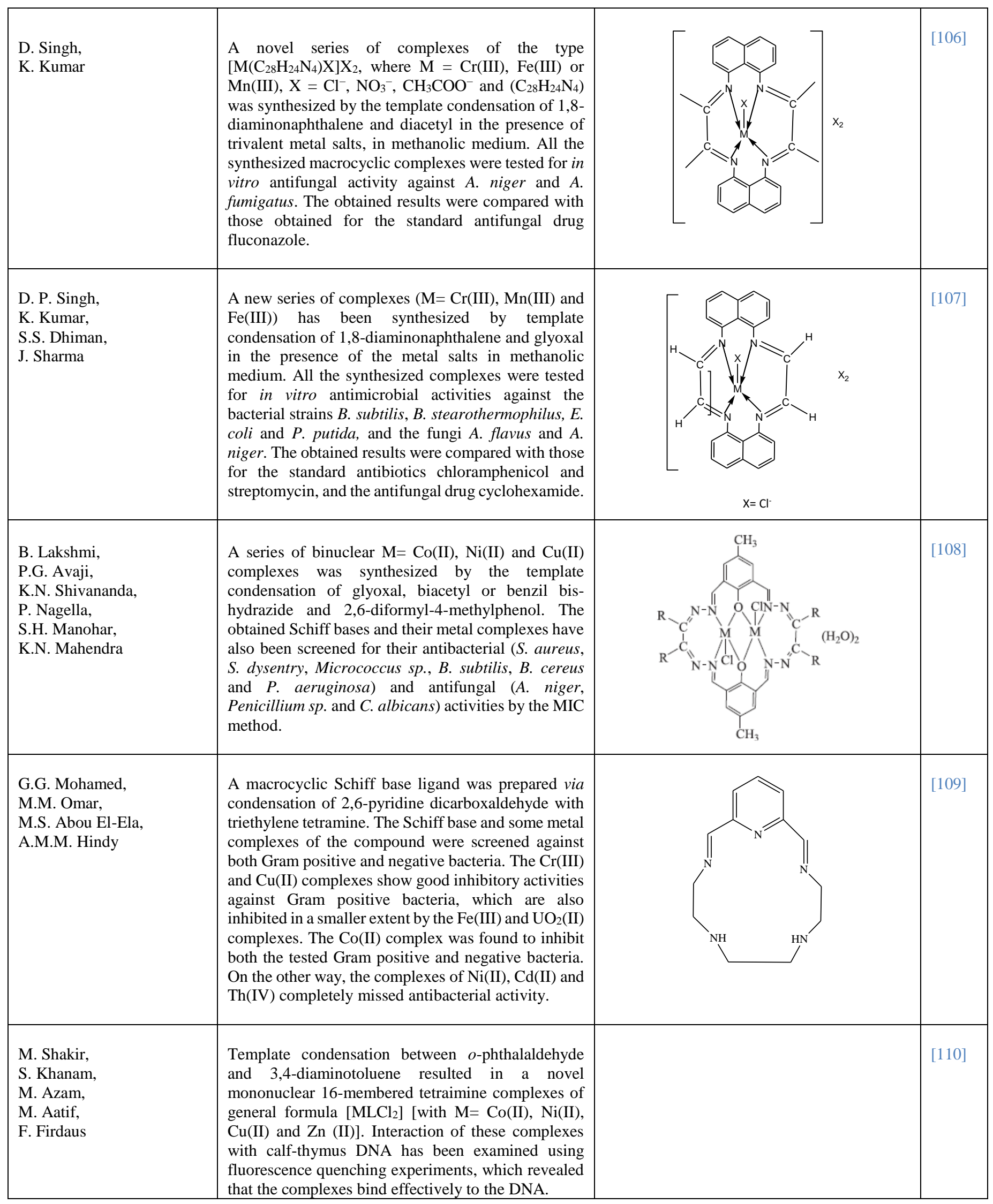




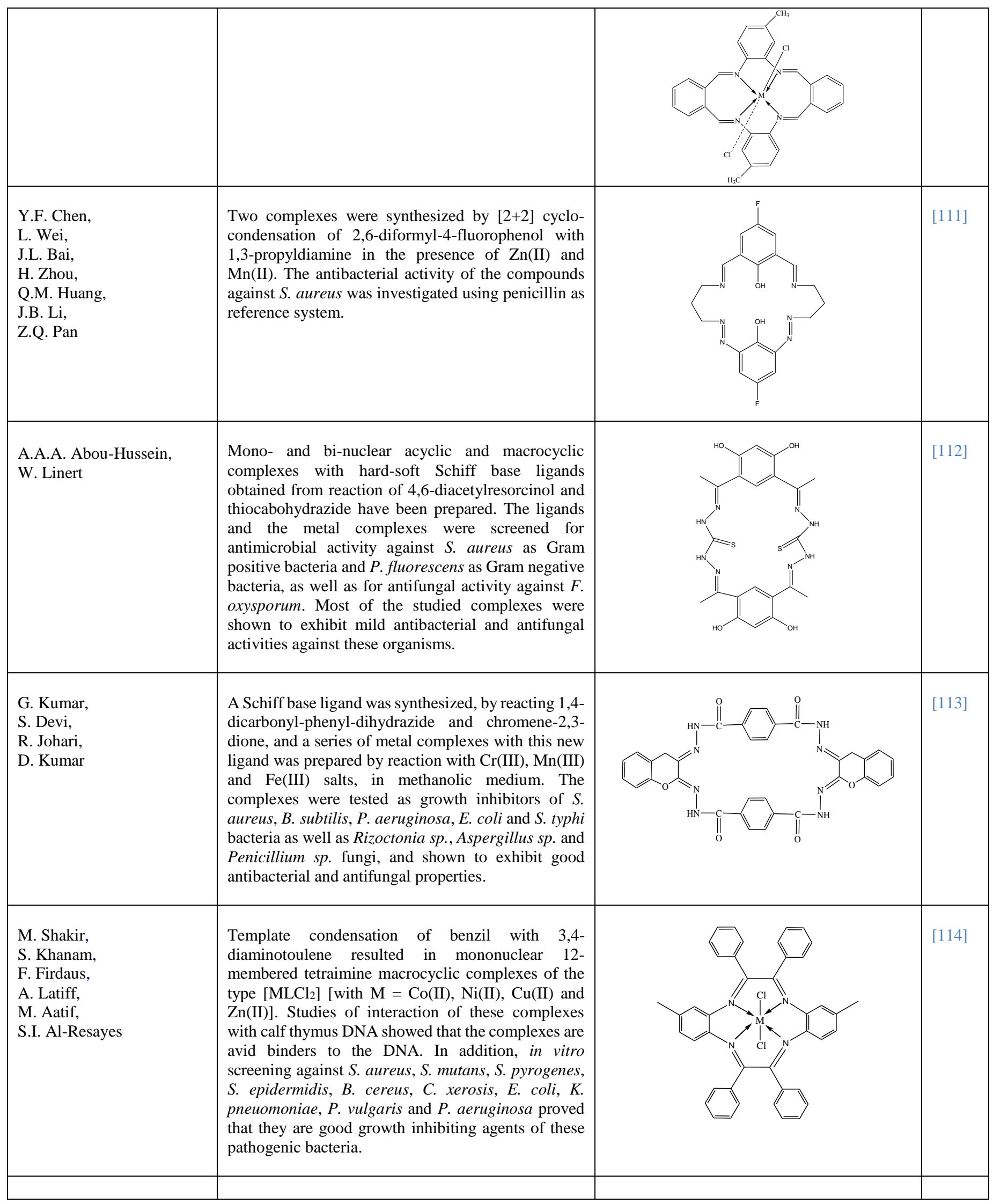




\begin{tabular}{|c|c|c|c|}
\hline $\begin{array}{l}\text { E.R. Krishna, } \\
\text { P.M. Reddy, } \\
\text { M. Sarangapani, } \\
\text { G. Hanmanthu, } \\
\text { B. Geeta, } \\
\text { K.S. Rani, } \\
\text { V. Ravinder }\end{array}$ & $\begin{array}{l}\text { Several tetraaza macrocyclic ligands were prepared } \\
\text { by condensation of ophthalaldehyde with several } \\
\text { substituted aromatic amines/azides and subsequently } \\
\text { used to synthesize a series of metal complexes of } \\
\mathrm{Ru}(\mathrm{II}) \text {, } \mathrm{Pd}(\mathrm{II}) \text { and } \mathrm{Pt}(\mathrm{II}) \text {. Both the ligands and } \\
\text { complexes were screened for their antibacterial } \\
\text { activities against Gram positive ( } S \text {. aureus and } B \text {. } \\
\text { subtilis) and Gram negative (E. coli and K. } \\
\text { pneumonia) bacteria using the MIC method. }\end{array}$ & $\mathrm{X}=$ substituted (di)amide, triazole or pyridine groups. $\mathrm{Y}=\mathrm{Cl}$. & [115] \\
\hline $\begin{array}{l}\text { O.I. Salam, } \\
\text { M.A. Al-Omar, } \\
\text { A. A. Fayed, } \\
\text { E.M. Flefel, } \\
\text { A.E. Amr }\end{array}$ & $\begin{array}{l}\text { A series of macrocyclic imides and Schiff-bases has } \\
\text { been prepared via the cyclocondensation of pyridine- } \\
\text { 2,6-dicarbonyl dichloride with L-ornithine methyl } \\
\text { ester, to give the corresponding macrocyclic bis- } \\
\text { esters. Microorganisms screening showed that most } \\
\text { of the newly synthesized compounds have anti- } \\
\text { microbial activities against } B \text {. subtilis, S. aureus and } \\
\text { E. coli bacteria and } C \text {. albicans and A. niger fungi that } \\
\text { are comparable to those of the reference drugs } \\
\text { ampicillin and ketaconazole. }\end{array}$ & $\mathrm{NH}_{2} \quad\left(\mathrm{CH}_{2}\right)_{2}$ & [116] \\
\hline S.C. Ruchi & $\begin{array}{l}\mathrm{Mn}(\mathrm{II}), \mathrm{Co}(\mathrm{II}), \mathrm{Ni}(\mathrm{II}) \text { and } \mathrm{Cu}(\mathrm{II}) \text { complexes with the } \\
\text { new tetradentate macrocyclic ligand } 1.2 .5 .6 \text {-tetraoxo- } \\
3,4,7,8 \text {-tetraaza- }(1,2,3,4,5,6,7,8) \text {-tetrabenzene(L) } \\
\text { were synthesized. The antimicrobial activities and } \\
\text { LD50 values of both the ligand and complexes, as } \\
\text { growth inhibiting agents against } B \text {. sublitis and } X \text {. } \\
\text { compestris bacteria and plant pathogenic fungi } R \text {. } \\
\text { solani and } R \text {. blast were investigated in vitro with } \\
\text { good results. }\end{array}$ & & [117] \\
\hline $\begin{array}{l}\text { I. Masih, } \\
\text { N. Fahmi, } \\
\text { R. kumar }\end{array}$ & $\begin{array}{l}\mathrm{Cr}(\mathrm{III}) \text { macrocyclic complexes were obtained by } \\
\text { template condensation of substituted } 1,2 \text {-diphenyl- } \\
\text { ethanones with } 1,2 \text {-phenylenediamine, } 4 \text {-chloro-1,2- } \\
\text { phenylenediamine and } 4 \text {-fluro- } 1,2-\text { phenylenediamine } \\
\text { in the presence of } \mathrm{CrCl}_{3} \cdot 6 \mathrm{H}_{2} \mathrm{O} \text {. The newly } \\
\text { synthesized ligands and complexes were screened for } \\
\text { antimicrobial (against bacterial strains E. coli and } B \text {. } \\
\text { subtilis, and fungi strain } F \text {. oxysporum), nematicidal } \\
(M \text {. incognita) and pesticidal (C. cephalonica) } \\
\text { activities, with promising results. }\end{array}$ & $\mathrm{Cl}$ & [118] \\
\hline $\begin{array}{l}\text { S. Rani, } \\
\text { S. Kumar, } \\
\text { S. Chandra }\end{array}$ & $\begin{array}{l}\text { A novel tetradentate nitrogen donor }\left[\mathrm{N}_{4}\right] \text { macrocyclic } \\
\text { ligand has been synthesized from condensation of } \\
\text { acetyl acetone with o-phenylene diamine. The } \\
\text { antimicrobial activities of the ligand and its } \mathrm{Pd}(\mathrm{II}) \text {, } \\
\mathrm{Pt}(\mathrm{II}), \mathrm{Ru}(\mathrm{III}) \text { and } \mathrm{Ir}(\mathrm{III}) \text { complexes against plant } \\
\text { pathogenic fungi } A \text {. porri and } F \text {. oxysporum, and } \\
\text { bacteria } X \text {. compestris and } P \text {. aeruginosa have been } \\
\text { screened in vitro, the results indicating that the Ru(III) } \\
\text { complex is highly active while the other metal } \\
\text { complexes show only moderate activity as compared } \\
\text { to the free ligand. }\end{array}$ & & [119] \\
\hline $\begin{array}{l}\text { H. Keypour, } \\
\text { M. Liyaghati-Delshad, }\end{array}$ & $\begin{array}{l}\text { Six new } M=C d(I I) \text { and } \mathrm{Zn}(\mathrm{II}) \text { complexes with a } \\
\text { macrocyclic Schiff base ligand produced by cyclo- }\end{array}$ & & [120] \\
\hline
\end{tabular}




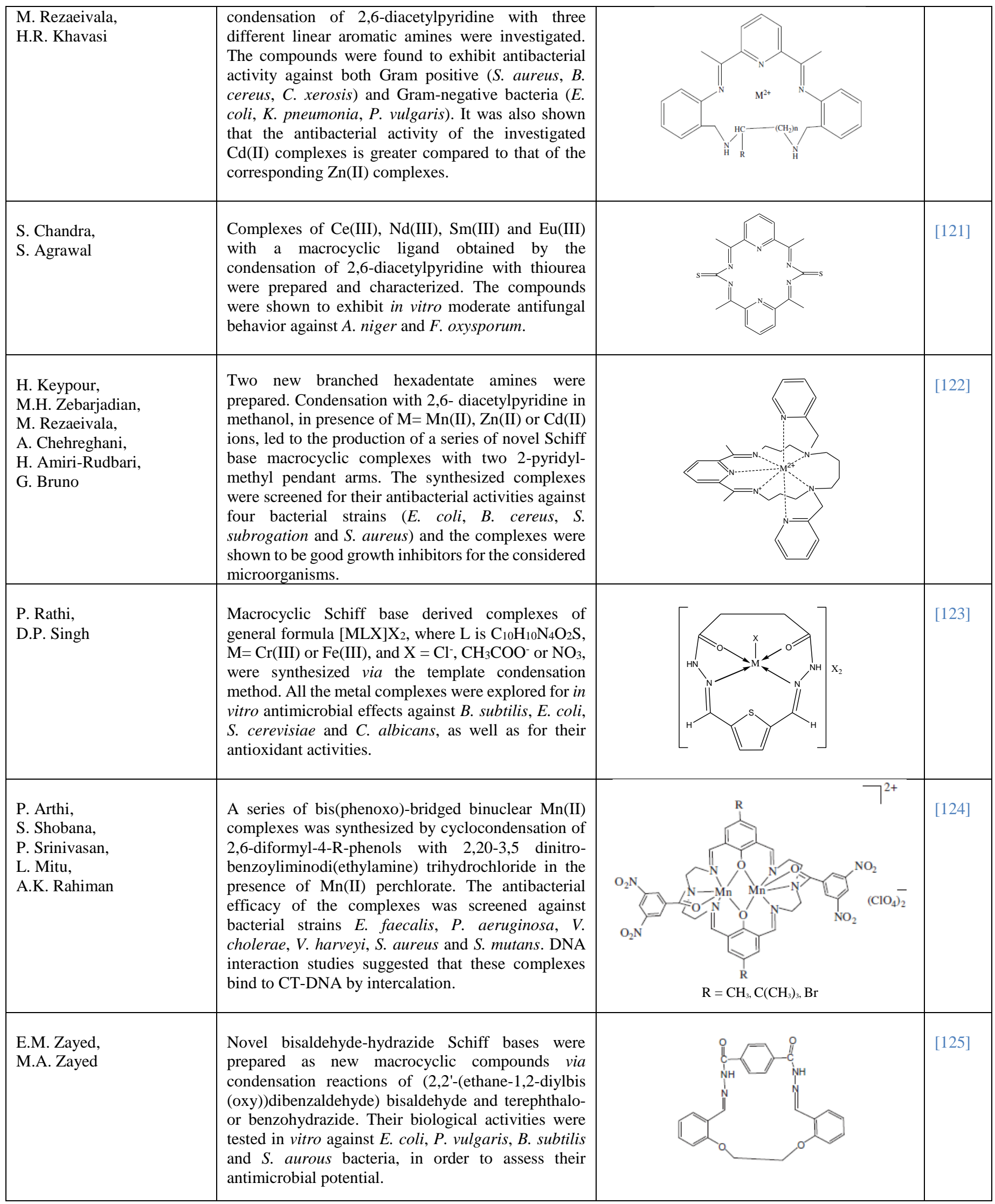




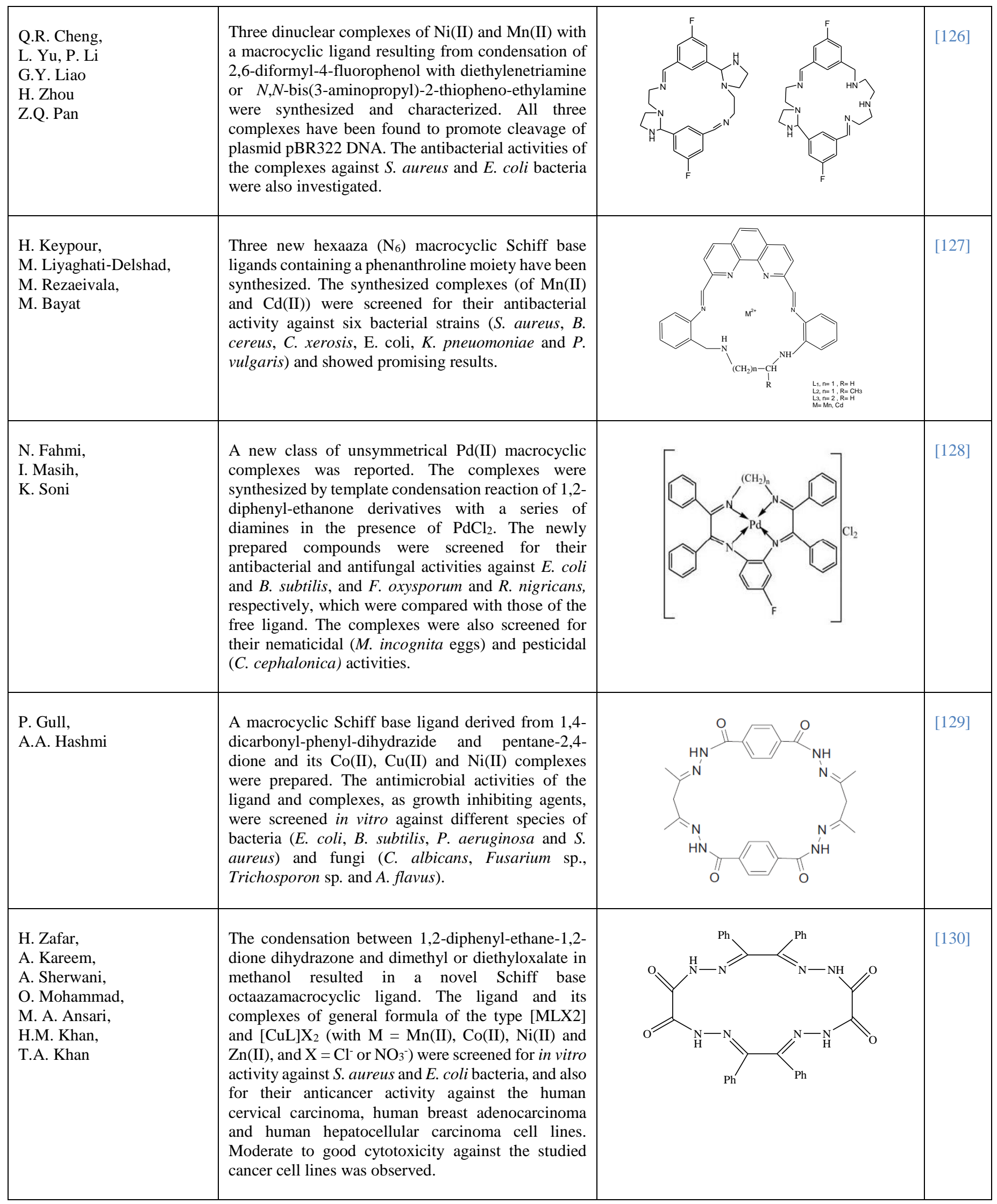




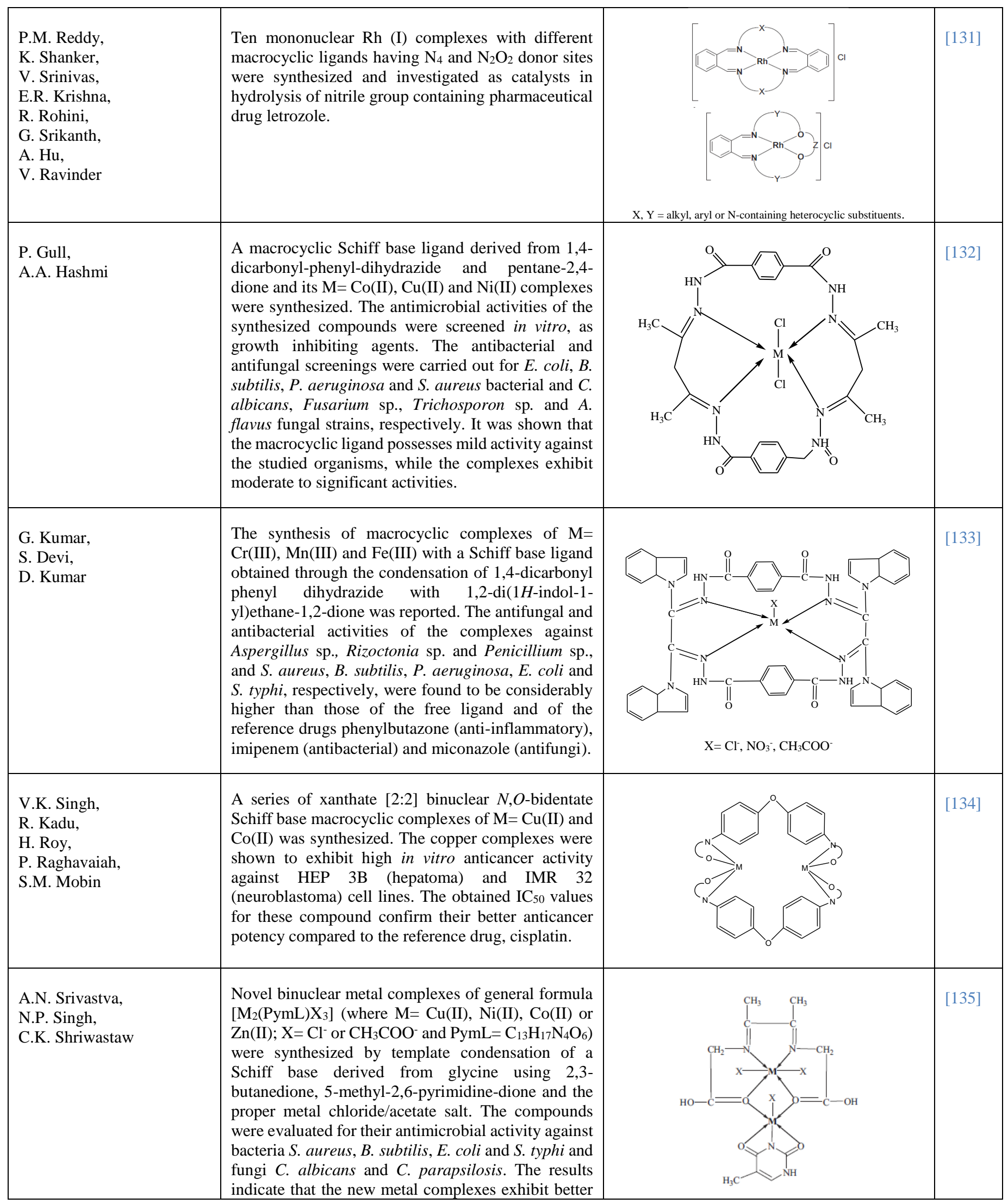




\begin{tabular}{|c|c|c|}
\hline & $\begin{array}{l}\text { activity than the free Schiff base against the } \\
\text { investigated bacteria and fungi. }\end{array}$ & \\
\hline $\begin{array}{l}\text { A.E. Amra, } \\
\text { M.A. Al-Omara }\end{array}$ & $\begin{array}{l}\text { A series of macrocyclic tripeptides and linear } \\
\text { dipeptide Schiff base derivatives was synthesized } \\
\text { from pyridine-3,5-dicarboxylic acid and L-phenyl- } \\
\text { alanine methyl ester. The antimicrobial activities } \\
\text { (against } B \text {. subtilis, } S \text {. aureus and } E \text {. coli) of some of } \\
\text { the novel compounds were found to be comparable } \\
\text { with that of streptomycin, chosen as control. }\end{array}$ & [136] \\
\hline $\begin{array}{l}\text { H.A. El-Boraey, } \\
\text { M.A. El-Salamony, } \\
\text { A.A. Hathout }\end{array}$ & $\begin{array}{l}\text { A novel penta-azamacrocyclic } 21-\text { membered }\left[\mathrm{N}_{5}\right] \\
\text { ligand and its complexes with } \mathrm{Co}(\mathrm{II}), \mathrm{Ni}(\mathrm{II}), \mathrm{Cu}(\mathrm{II}) \text {, } \\
\mathrm{Ru}(\mathrm{III}) \text { and } \mathrm{Pd}(\mathrm{II}) \text { were prepared and characterized. } \\
\text { The ligand and some of the complexes were tested for } \\
\text { their inhibitory effect on the growth of bacteria strains } \\
\text { S. pyogenes and E. coli, the activity data showing that } \\
\text { most of the tested compounds exhibit remarkable } \\
\text { antibacterial activity against these organisms. }\end{array}$ & [137] \\
\hline $\begin{array}{l}\text { Z. Parsaee, } \\
\text { K. Mohammadi }\end{array}$ & $\begin{array}{l}\text { Several new macrocyclic bridged dianilines tetra- } \\
\text { dentate with } \mathrm{N}_{4} \text { coordination sphere Schiff base } \\
\text { ligands and their } \mathrm{Ni}(\mathrm{II}) \text { complexes were synthesized. } \\
\text { All the Schiff bases and their complexes have been } \\
\text { essayed in vitro as antibacterial agents against two } \\
\text { Gram negative (E. coli and } P \text {. aeruginosa) and two } \\
\text { Gram positive ( } S \text {. aureus and } S \text {. epidermidis) bacteria. } \\
\text { The Ni(II) complexes were found to be more active } \\
\text { than the parent free macrocycle Schiff bases. }\end{array}$ & [138] \\
\hline $\begin{array}{l}\text { H. Keypour, } \\
\text { M. Mahmoudabadi, } \\
\text { A. Shooshtari, } \\
\text { L. Hosseinzadeh, } \\
\text { F. Mohsenzadeh, } \\
\text { R.W. Gable }\end{array}$ & $\begin{array}{l}\text { A new diamine ligand, 2,20-(piperazine-1,4-diylbis } \\
\text { (methylene)dianiline, was synthesized by reaction of } \\
\text { 2-nitrobenzyl chloride and piperazine. Its } \mathrm{M}=\mathrm{Mn} \text { (II) } \\
\text { and } \mathrm{Zn} \text { (II) complexes were prepared via the metal } \\
\text { template cyclocondensation method and tested for in } \\
\text { vitro antibacterial properties against } B \text {. subtilis, B. } \\
\text { thuringiensis, S. Aprophyticus, Pectobacterium sp. } \\
\text { and P. fluorescens. The complexes show appreciable } \\
\text { antibacterial properties, in some of the cases better } \\
\text { than those of tobramycin and tetracycline drugs, } \\
\text { which were selected as standards. }\end{array}$ & [139] \\
\hline $\begin{array}{l}\text { P. Gull, } \\
\text { B.A. Babgi, } \\
\text { A.A. Hashmi }\end{array}$ & $\begin{array}{l}\text { A macrocyclic Schiff base ligand derived from 1,4- } \\
\text { dicarbonyl-phenyl-dihydrazide and glyoxal, and its } \\
\mathrm{Ni}(\mathrm{II}), \mathrm{Cu}(\mathrm{II}) \text { and } \mathrm{Co}(\mathrm{II}) \text { complexes were synthesized. } \\
\text { All the synthesised compounds were screened for } \\
\text { their antimicrobial properties against some strains of } \\
\text { bacteria ( } S \text {. aureus, B. subtilis, and } E \text {. coli) and fungi } \\
\text { (C. albicans, A. flavus and } A \text {. niger). The antioxidant } \\
\text { activity of the compounds was also studied through } \\
\text { scavenging effect on radicals, with the copper } \\
\text { complex showing enhanced antioxidant activity when } \\
\text { compared with the other studied metal complexes. }\end{array}$ & [140] \\
\hline $\begin{array}{l}\text { M. Shakir, } \\
\text { N. Bano, }\end{array}$ & $\begin{array}{l}\text { 12-membered ring Schiff base macrocyclic } \\
\text { complexes of dichloro[5,6;11,12-dibenzophenone- }\end{array}$ & [141] \\
\hline
\end{tabular}




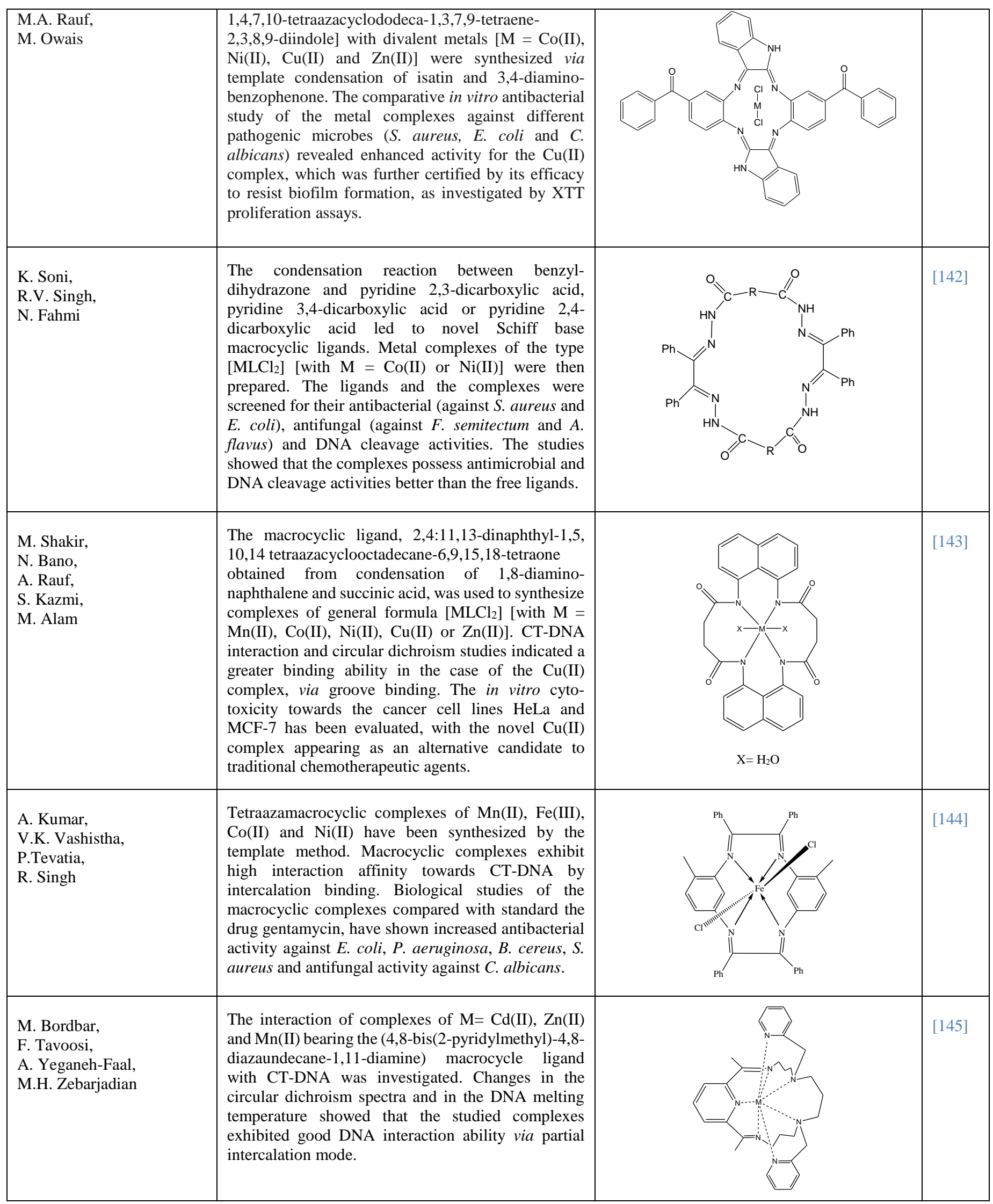




\begin{tabular}{|c|c|c|c|}
\hline $\begin{array}{l}\text { H. Keypour, } \\
\text { M. Mahmoudabadi, } \\
\text { A. Shooshtari, } \\
\text { M. Bayat, } \\
\text { F. Mohsenzadeh, } \\
\text { R.W. Gable }\end{array}$ & $\begin{array}{l}\text { New Cd(II) macrocyclic Schiff-base complexes were } \\
\text { prepared via metal template cyclocondensation of } \\
\text { 2,2'-(piperazine-1,4-diylbis(methylene) dianiline and } \\
\text { 2,6-pyridinedicarbaldehyde or } 2,6 \text {-diacetylpyridine. } \\
\text { The complexes were tested for in vitro antibacterial } \\
\text { properties against B. anthracis, B. thuringiensis, B. } \\
\text { subtilis, } S \text {. griseus, S. enteritidis, S. maltophilia, P. } \\
\text { fluorescens, S. typhi and Ralstoniasolanacearum. } \\
\text { Some of the compounds were found to exhibit better } \\
\text { biological activity than the standard antibiotics } \\
\text { chlortetracycline and penicillin. }\end{array}$ & & [146] \\
\hline $\begin{array}{l}\text { O.A. El-Gammal, } \\
\text { A.F. Al-Hossainy, } \\
\text { S.A. El-Brashy }\end{array}$ & $\begin{array}{l}\text { The macrocyclic ligand, }(2 E) \text {-3,6,10,13-tetramethyl- } \\
\text { 2,7,9,14-tetraaza-1,8 (1,4)-dibenzenacyclotetradeca- } \\
\text { phane-2,6,9,13-tetraene and its } \mathrm{Co}(\mathrm{II}), \mathrm{Ni}(\mathrm{II}) \text { and } \\
\mathrm{Cu}(\mathrm{II}) \text { complexes were isolated and characterized. } \\
\text { The compounds were screened in vitro against } \\
\text { pathogenic bacteria, and concluded to have better } \\
\text { inhibition proprieties against Gram positive ( } S \text {. } \\
\text { pyogenes and } S \text {. epidermidis) than against Gram } \\
\text { negative }(P \text {. vulgaris and Klebsiella sp.) bacteria. The } \\
\text { complexes were also found to have some protective } \\
\text { effect on DNA. }\end{array}$ & & [147] \\
\hline $\begin{array}{l}\text { P. Jain, } \\
\text { V. Singh, } \\
\text { S. Ali, } \\
\text { V. Tripathi, } \\
\text { U. Saraswat }\end{array}$ & $\begin{array}{l}\text { A macrocyclic Schiff base ligand was prepared by } \\
\text { condensation of 1,3-dicarbonyl-phenyl-dihydrazide } \\
\text { with } 4,4 \text {-difluorobenzil, and its } \mathrm{Co}(\mathrm{II}), \mathrm{Ni}(\mathrm{II}), \mathrm{Cu}(\mathrm{II}) \\
\text { and } \mathrm{Zn} \text { (II) complexes were subsequently synthesized. } \\
\text { The bacterial growth inhibiting potential of the } \\
\text { synthesized ligand and all prepared metal complexes } \\
\text { was assessed against Gram positive ( } S \text {. aureus and } B \text {. } \\
\text { subtilis) and Gram negative (E. coli, P. aeruginosa } \\
\text { and } S \text {. typhi) bacterial strains. The anticancer activity } \\
\text { of the synthesized compounds against squamous cell } \\
\left.\text { carcinoma ( } \mathrm{SCC}_{4}\right) \text {, head and neck cancer cell lines } \\
\text { was also evaluated. }\end{array}$ & & [148] \\
\hline $\begin{array}{l}\text { A.G.B. Dileepan, } \\
\text { T.D. Prakash, } \\
\text { A.G. Kumar, } \\
\text { P.S. Rajam, } \\
\text { V.V. Dhayabaran, } \\
\text { R. Rajaram }\end{array}$ & $\begin{array}{l}\text { A new class of macrocyclic compounds with } \\
\text { promising antioxidant and antibacterial activity was } \\
\text { reported. The biological properties and possible } \\
\text { pharmacological applications of the compounds were } \\
\text { explored by performing antioxidant and antibacterial } \\
\text { tests. The antimicrobial potencies of the newly } \\
\text { synthesized compounds were examined by } \\
\text { performing in vitro antibacterial evaluation. E. } \\
\text { faecalis, B. megaterium, } S \text {. epidermidis, S. aureus, V. } \\
\text { cholera, E. coli, S. typhi and S. flexneri were used as } \\
\text { test bacteria. }\end{array}$ & & [149] \\
\hline $\begin{array}{l}\text { J. Liu, } \\
\text { Y. Lin, } \\
\text { M. Liu, } \\
\text { S. Wang, } \\
\text { Y. Li, } \\
\text { X. Liu, } \\
\text { L. Tian }\end{array}$ & $\begin{array}{l}\text { Six new triorganotin complexes were synthesized by } \\
\text { one-pot reaction of 5-aminosalicylic acid, salicyl- } \\
\text { aldehyde and triorganotin hydroxide. Bioassay results } \\
\text { against two human tumor cell types (A549 and HeLa) } \\
\text { demonstrated that the complexes are efficient } \\
\text { cytostatic agents and may be explored as potential } \\
\text { antitumor drugs. }\end{array}$ & $\mathrm{X}=\mathrm{H}, \mathrm{CH} \mathrm{O} ; \mathrm{R}=\mathrm{Ph}$, cyclohexyl, $\mathrm{CH}_{2} \mathrm{C}\left(\mathrm{CH}_{3}\right)_{2} \mathrm{Ph}$ & [150] \\
\hline
\end{tabular}




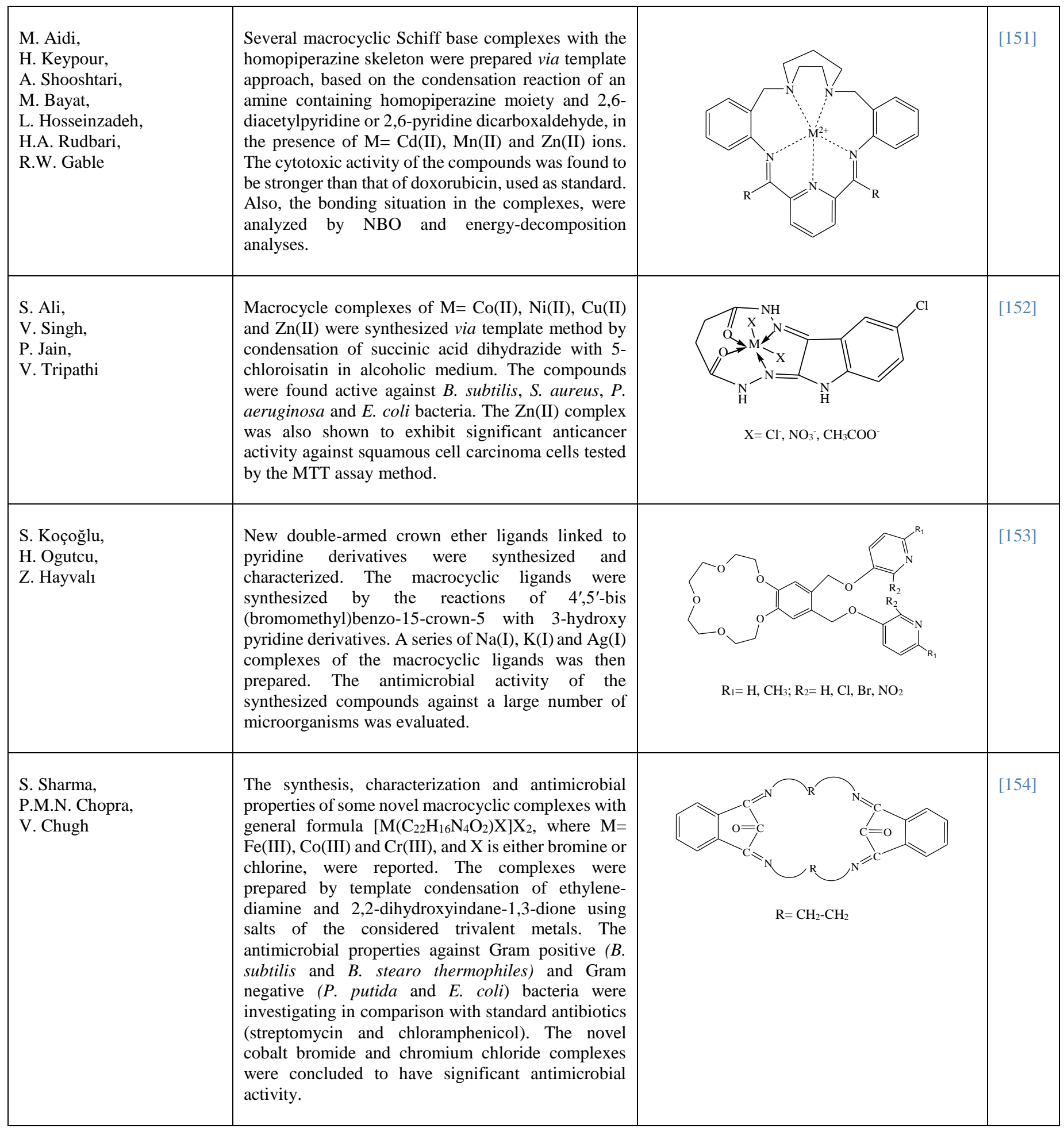

\section{Acknowledgements}


The Payame Noor University is acknowledged for partial financial support to this study. Financial support from Project PTDC/QEQ-QFI/3284/2014 - POCI-01-0145-FEDER-016617, funded by the Portuguese "Fundação para a Ciência e a Tecnologia" (FCT) and FEDER/COMPETE 2020EU is also acknowledged. The Coimbra Chemistry Centre (CQC) is supported by FCT, through the project UID/QUI/UI0313/2019, also cofounded by FEDER/COMPETE 2020-EU.

\section{References}

[1] E. W. Gerner and F. L. Meyskens, Nat. Rev. Cancer, 4 (2004) 781-792.

[2] A. K. Handa, T. Fatima and A. K. Mattoo, Front. Chem., 6 (2018) Art. no 10.

[3] L. J. Marton and A. E. Pegg, Annu. Rev. Pharmacol. Toxicol., 35 (1995) 55-91.

[4] A. E. Pegg, Cancer Res., 48 (1988) 759-774.

[5] H. M. Wallace, A. V. Fraser and A. Hughes, Biochem. J., 376 (2003) 1-14.

[6] H. Bachrach, Plant Physiol. Biochem., 48 (2010) 490-495.

[7] P. Shah and E. Swiatlo, Mol. Microbiol., 68 (2008), 4-16.

[8] L. Valdés-Santiago and J. Ruiz-Herrera, Front. Chem., 1 (2013), 42.

[9] D. A. Lewenhoeck, Phil. Trans. Royal Soc. London, 12 (1677) 1040-1046.

[10] H. W. Dudley, O. Rosenheim and W. W. Starling, Biochem. J., 20 (1926) 1082-1094.

[11] F. Wrede, Dtsch. Med. Wochenschr., 51 (1925) 24.

[12] L. Brieger, Weitere Untersuchungen über Ptomaine, Berlin, Germany, August Hirschwald, 1885.

[13] A. E. Pegg, J. Biol. Chem., 291 (2016) 14904-14912.

[14] L. Miller-Fleming, V. Olin-Sandoval, K. Campbel and M. Ralser, J. Mol. Biol., 427 (2015) 3389-3406.

[15] C. Kahana, J. Biol. Chem., 293 (2018) 18730-18735.

[16] C. Kahana, J. Biol. Chem., 285 (2010) 12474-12481.

[17] G. Iacomino, G. Picariello and L. D'Agostino, Biochim. Biophys. Acta, 1823 (2012) 17451755.

[18] Y. Terui, M. Ohnuma, K. Hiraga, E. Kawashima and T. Oshima, Biochem. J., 388 (2005) 427-433.

[19] V. Battaglia, C. De Stefano Shields, T. Murray-Stewart and R. A. Casero, Jr., Amino Acids, 46 (2014) 511-519.

[20] S. L. Nowotarski, P. M. Woster and R. A. Casero, Jr., Expert. Rev. Mol. Med. 15:e3 (2013). doi:10.1017/erm.2013.3 
[21] M. D. Bratek-Wiewiorowska, M. Alejska, M. Figlerowicz, J. Barciszewski, M. Wiewiorowski and M. Jaskolski, Pure Appl. Chem., 59 (1987) 407-414.

[22] T. Thomas and T. J. Thomas, Mol. Life Sci., 58 (2001) 244-258.

[23] M. L. Antonelli, S. Balzamo, V. Carunchio, E. Cernia and R. Purrello, J. Inorg. Biochem., 32 (1988) 153-161.

[24] H. Tabor and C. W. Tabor, Pharmacol. Rev., 16 (1964) 245-300.

[25] M. Rezaeivala and H. Keypour, Coord. Chem. Rev., 280 (2014) 203-253.

[26] E. L. Gavey and M. Pilkington, Coord. Chem. Rev., 296 (2015) 125-152.

[27] R. Jastrzab, M. T. Kaczmarek, M. Nowak, A. Trojanowska and M. Zabiszak, Coord. Chem. Rev., 351 (2017) 32-44.

[28] S. Polarz, S. Landsmann and A. Klaiber, Angew. Chem. Int. Ed., 53 (2014) 946-954.

[29] H. Schiff, Ann. Chem., 131 (1864) 118-119.

[30] N. E. Borisova, M. D. Reshetova and Y. A. Ustynyuk, Chem. Rev., 107 (2007) 146-147.

[31] A. E. Martell, J. Perutka and D. Kong, Coord. Chem. Rev., 55 (2001) 216-217.

[32] P. Guerriero, S. Tamburini and P. A. Vigato, Coord. Chem. Rev., 139 (1995) 17-243.

[33] P. A. Vigato and S. Tamburini, Coord. Chem. Rev., 248 (2004) 1717-2128.

[34] S. Polarz, J. A. Odendal, S. Hermann and A. Klaiber, Curr. Opin. Colloid Interface Sci., 20 (2015) 151-160.

[35] J. C. Pessoa and I. Correia, Coord. Chem. Rev., 388 (2019) 227-247.

[36] R. Golbedaghi, L. L. G. Justino, R. Fausto, S. Safarabadia and M. Alvandi, Inorg. Chim. Acta, 495 (2019) 1-10.

[37] R. Golbedaghi, R. Fausto, S. Salehzadeh, M. Tofani and S. Safaraabadi, Inorg. Chim. Acta, 480 (2018) 27-32.

[38] R. Golbedaghi, S. Azimi, A. Molaei, M. Hatami and B. Notash, J. Mol. Struct., 1146 (2017) 309-313.

[39] R. Golbedaghi and R. Fausto, Polyhedron, 155 (2018) 1-12.

[40] R. Golbedaghi, M. Rezaeivala, M. Khalili, B. Notash and J. Karimi, J. Mol. Struct., 1125 (2016) 144-148.

[41] A. Aminimanesh, R. Golbedaghi and L. Hadi, Org. Prep. Proc. Int., (2019) 1-6.

[42] V. McKee, Adv. Inorg. Chem., 40 (1993) 323-399.

[43] J. Nelson, V. McKee and G. Morgan, Progr. Inorg. Chem., 47 (1998) 167-316.

[44] S. Brooker, Coord. Chem. Rev., 222 (2001) 33-56.

[45] S. Brooker, Eur. J. Inorg. Chem., (2002) 2535-2547.

[46] G. Topal, R. Tümerdem, I. Basaran, A. Gümüş and U. Cakir, Int. J. Mol. Sci., 8 (2007) 933942. 
[47] W. Al Zoubi, F. Kandil and M. K. Chebani, Arab. J. Chem., 9 (2016) 526-531.

[48] Y. W. Choi, G. J.Park, Y. J. Na, H. Y. Jo, S. A. Lee, G. R.You and C. Kim, Sens. Actuators B, 194 (2014) 343-352.

[49] W. Al Zoubi, F. Kandil and M. K. Chebani, Arab. J. Chem., 9 (2016) 626-632.

[50] J. K. Lanyi, J. Biol. Chem., 272 (1997) 31209-31212.

[51] M. S. Singh and S. Chowdhury, RSC Advances, 2 (2012) 4547-4592.

[52] P. A. Vigato and S. Tamburini, Coord. Chem. Rev., 252 (2008) 1871-1995.

[53] M. P. Kumar, N. Vamsikrishna, G. Ramesh, N. J. P. S. Jagadeesh and B. Nanubolu, J. Coord. Chem., 70 (2017) 1368-1388.

[54] P. J. Dyson and G. Sava, Dalton Trans., 16 (2006) 1929-1933.

[55] S. Trzaska, Chem. Eng. News., 83 (2005) 25.

[56] D. P. Carpenter, "Reputation and power: organizational image and pharmaceutical regulation at the FDA", Princeton University Press, Princeton, NJ (USA), 2010.

[57] "Approval Summary for cisplatin for Metastatic ovarian tumors". FDA Oncology Tools. Food and Drug Administration, Center for Drug Evaluation and Research. 1978.

[58] E. Wiltshaw, Platinum Metals Rev., 23 (1979) 90-8.

[59] D. Lebwohl and R. Canetta, Eur. J. Cancer, 34 (1998) 1522-1534.

[60] H. Brunner, P. Hankofer, U. Holzinger, B. Treittinger and H. Schönenberger, Eur. J. Med. Chem., 25 (1990) 35-44.

[61] N. Farrell, Y. Qu and M. P. Hacker, J. Med. Chem., 33 (1990) 2179-2184.

[62] N. Farrell, Y. Qu, L. Feng and B. van Houten, Biochem., 29 (1990) 9522-9531.

[63] J. D. Roberts, B. van Houten, Y. Qu, N. P. Farrell, Nucleic Acids Res., 17 (1989) 97199733.

[64] C. Navarro-Ranninger, F. Zamora, J. M. Perez, I. Lopez-Solera, S. Martinez-Carrera, J. R. Masaguer and C. Alonso, J. Inorg. Biochem., 46 (1992) 267-279.

[65] P. A. Vigato, S. Tamburini and L. Bertolo, Coord. Chem. Rev., 251 (2007) 1311-1492.

[66] P. Guerriero, P. A. Vigato, D. E. Fenton and P. C. Hellier, Acta Chem. Scand., 46 (1992) 1025-1046.

[67] C. Schattschneider, S. D. Kettenmann, S. Hinojosa, J. Heinrich and N. Kulak, Coord. Chem. Rev., 385 (2019) 191-207.

[68] J. Y. Jia, Q. H. Zhao, Y. Liu, Y. Z. Gui, G. Y. Liu, D. Y. Zhu, C. Yu and Z. Hong, Acta Pharmacol. Sin., 34 (2013) 976-982.

[69] R. P. Nowak, S. L. De Angelo, D. Buckley, Z. He, K. A. Donovan, J. An, N. Safaee, M. P. Jedrychowski, C. M. Ponthier, M. Ishoey, T. Zhang, J. D. Mancias, N. S. Gray, J. E. Bradner and E. S. Fischer, Nat. Chem. Biol., 14 (2018) 706-714. 
[70] C. A. Lipinski, F. Lombardo, B. W. Dominy and P. J. Feeney, Adv. Drug Deliv. Rev., 23 (1997) 3-25.

[71] J. Gao, F. R. Woolley and R. A. Zingaro, J. Med. Chem., 48 (2005) 7192-7197.

[72] B. H. M. Mruthyunjayaswamy, Y. J. Omkar, B. Ijare, S. G. Patil and S. M. Kudari, Transit. Met. Chem., 30 (2005) 234-242.

[73] H. I. Ugras, I. Basaran, T. Kilic, U. Cakir, J. Heterocyclic Chem., 43 (2006) 1679-1684.

[74] N. Nishat, M. M. Haq, T. Ahamad and V. Kumar, J. Coord. Chem., 60 (2007) 85-96.

[75] P. M. Reddy, A. V. S. S. Prasad, K. Shanker and V. Ravinder, Spectrochim. Acta A, 68 (2007) 1000-1006.

[76] H. Khanmohammadi, R. Arabahmadi, M. H. Abnosi and H. R. Khavasi, Polyhedron, 26 (2007) 4963-4970.

[77] S. Sreedaran, K. S. Bharathi, A. K. Rahiman, L. Jagadish, V. Kaviyarasan and V. Narayanan, Polyhedron, 27 (2008) 2931-2938.

[78] D. P. Singh, R. Kumar and J. Singh, Eur. J. Med. Chem., 44 (2009) 1731-1736.

[79] P. M. Reddy, Y. P. Ho, K. Shanker, R. Rohini and V. Ravinder, Eur. J. Med. Chem., 44 (2009) 2621-2625.

[80] P. G. Avaji, C. H. V. Kumar, S. A. Patil, K. N. Shivananda and C. Nagaraju, Eur. J. Med. Chem., 44 (2009) 3552-3559.

[81] D. P. Singh, R. Kumar and J. Singh, J. Enzyme Inhib. Med. Chem., 24 (2009) 883-889.

[82] D. P. Singh, K. Kumar, S. S. Dhiman and J. Sharma, J. Enzyme Inhib. Med. Chem., 24 (2009) 795-803.

[83] K. Shanker, P. M. Reddy, R. Rohini, Y. P. Ho and V. Ravinder, J. Coord. Chem., 62 (2009) 3040-3049.

[84] S. Sreedaran, K. S. Bharathi, A. K. Rahiman, R. Prabu, R. Jegadeesh, N. Raaman and V. Narayanan, J. Coord. Chem., 62 (2009) 3073-3084.

[85] N. Raman, S. J. Raja, J. Joseph and A. Sakthivel, Russ. J. Coord. Chem., 34 (2008) 842848.

[86] D. P. Singh, V. Malik, R. Kumar, K. Kumar and J. Singh, Russ. J. Coord. Chem., 35 (2009) 740-745.

[87] N. Nishat, R. U. Din and S. Dhyani, J. Coord. Chem., 62 (2009) 996-1004.

[88] D. P. Singh, R. Kumar, M. Kamboj and K. Jain, J. Coord. Chem., 62 (2009) 2995-3002.

[89] N. Nishat and A. S. Dhyani, J. Coord. Chem., 62 (2009) 3003-3011.

[90] P. G. Avaji and S. A. Patil, J. Enzyme Inhib. Med. Chem., 24 (2009) 140-150.

[91] G. B. Bagihalli and S. A. Patil, J. Coord. Chem., 62 (2009) 1690-1700.

[92] S. Chandra, S. Verma, U. Dev and N. Joshi, J. Coord. Chem., 62 (2009) 1327-1335. 
[93] K. Shanker, R. Rohini, V. Ravinder, P. M. Reddy and Y. P. Ho, Spectrochim. Acta A, 73 (2009) 205-211

[94] A. P. Mishra, R. K. Mishra and S. P. Shrivastava, J. Serb. Chem. Soc., 74 (2009) 523-535.

[95] H. Khanmohammadi, H. Keypour, M. S. Fard and M. H. Abnosi, J. Incl. Phenom. Macrocycl. Chem., 63 (2008) 97-108.

[96] D. Singh, K. Kumar, R. Kumar and J. Singh, J. Serb. Chem. Soc., 75 (2010) 217-228.

[97] D. P. Singh, K. Kumar, S. S. Dhiman and J. Sharma, J. Enzyme Inhib. Med. Chem., 25 (2010) 21-28.

[98] S. A. Patil, U. V. Kamble and P. S. Badami, J. Macromol. Sci. A, 47 (2010) 816-827.

[99] U. V. Kamble, S. A. Patil and P. S. Badami, J. Incl. Phenom. Macrocycl. Chem., 68 (2010) 347-358.

[100] D. P. Singh and K. Kumar, J. Coord. Chem., 63 (2010) 3313-3321.

[101] D. P. Singh, V. Malik, R. Kumar and K. Kumar, Russ. J. Coord. Chem., 36 (2010) 220225.

[102] F. Firdaus, K. Fatma, M. Azam and M. Shakir, J. Coord. Chem., 63 (2010) 3956-3968.

[103] D. P. Singh, V. Grover, R. Kumar and K. Jain, J. Enzyme Inhib. Med. Chem., 25 (2010) 445-449.

[104] D. P. Singh, K. Kumar, C. Sharma and K. R. Aneja, J. Enzyme Inhib. Med. Chem., 25 (2010) 544-550.

[105] H. Khanmohammadi, S. Amani, M. H. Abnosi and H. R. Khavasi, Spectrochim. Acta A, 77 (2010) 342-347

[106] D. Singh and K. Kumar, J. Serb. Chem. Soc., 75 (2010) 475-482.

[107] D. P. Singh, K. Kumar, S. S. Dhiman and J. Sharma, J. Enzyme Inhib. Med. Chem., 25 (2010) 21-28.

[108] B. Lakshmi, P. G. Avaji, K. N. Shivananda, P. Nagella, S. H. Manohar and K. N. Mahendra, Polyhedron, 30 (2011) 1507-1515.

[109] G. G. Mohamed, M. M. Omar, M. S. A. El-Ela and A. M. M. Hindy, Toxicol. Environ. Chem., 93 (2011) 57-72.

[110] M. Shakir, S. Khanam, M. Azam, M. Aatif and F. Firdaus, J. Coord. Chem., 64 (2011) 3158-3168.

[111] Y. F. Chen, L. Wei, J. L Bai, H. Zhou, Q. M. Huang, J. B. Li and Z. Q. Pan, J. Coord. Chem., 64 (2011) 1153-1164.

[112] A. A. A. Abou-Hussein and W. Linert, Spectrochim. Acta A, 95 (2012) 596-609.

[113] G. Kumar, S. Devi, R. Johari and D. Kumar, Eur. J. Med. Chem., 52 (2012) 269-274.

[114] M. Shakir, S. Khanam, F. Firdaus, A. Latiff, M. Aatif and S. I. Al-Resaye, Spectrochim. Acta A, 93 (2012) 354-362. 
[115] E. R. krishna, P. M. Reddy, M. Sarangapani, G. Hanmanthu, B. Geeta, K. S. Rani and V. Ravinder, Spectrochim. Acta A, 97 (2012) 189-196.

[116] O. I. Salam, M. A. Al-Omar, A. A. Fayed, E. M. Flefel and A. E. Amr, Molecules, 17 (2012) $14510-14521$.

[117] S. C. Ruchi, Spectrochim. Acta A, 103 (2013) 338-348.

[118] I. Masih, N. Fahmi and R. kumar, J. Enzyme Inhib. Med. Chem., 28 (2013) 33-40.

[119] S. Rani, S. Kumar and S. Chandra, Spectrochim. Acta A, 118 (2014) 244-250.

[120] H. Keypour, M. Liyaghati-Delshad, M. Rezaeivala and H. R. Khavasi, J. Iran. Chem Soc., 11 (2014) 1473-1482.

[121] S. Chandra and S. Agrawal, Spectrochim. Acta A, 124 (2014) 564-570.

[122] H. Keypour, M. H. Zebarjadian, M. Rezaeivala, A. Chehreghani, H. Amiri-Rudbari and G. Bruno, J. Iran. Chem Soc., 11 (2014) 101-109.

[123] P. Rathi and D. P. Singh, J. Mol. Struct., 1100 (2015) 208-214.

[124] P. Arthi, S. Shobana, P. Srinivasan, L. Mitu and A. K. Rahiman, Spectrochim. Acta A, 143 (2015) 49-58

[125] E. M. Zayed and M. A. Zayed, Spectrochim. Acta A, 143 (2015) 81-90.

[126] Q. R. Cheng, L. Yu, P. Li, G. Y. Liao, H. Zhou and Z. Q. Pan, Transit. Met. Chem., 40 (2015) 789-797.

[127] H. Keypour, M. Liyaghati-Delshad, M. Rezaeivala and M. Bayat, J. Iran. Chem Soc., 12 (2015) 621-630.

[128] N. Fahmi, I. Masih and K. Soni, J. Macromol. Sci. A, 52 (2015) 548-560.

[129] P. Gull and A. A. Hashmi, J. Braz. Chem. Soc., 26 (2015) 1331-1337.

[130] H. Zafar, A. Kareem, A. Sherwani, O. Mohammad, M. A. Ansari, H. M. Khan and T. A. Khan, J. Photochem. Photobiol. B: Biology, 142 (2015) 8-19.

[131] P. M. Reddy, K. Shanker, V. Srinivas, E. R. Krishna, R. Rohini, G. Srikanth, A. Hu and V. Ravinder, Spectrochim. Acta A, 139 (2015) 43-48.

[132] P. Gull and A. A. Hashmi, J. Braz. Chem. Soc., 26 (2015) 1331-1337.

[133] G. Kumar, S. Devi and D. Kumar, J. Mol. Struct., 1108 (2016) 680-688.

[134] V. K. Singh, R. Kadu, H. Roy, P. Raghavaiah and S. M. Mobin, Dalton Trans., 45 (2016) 1443-1454.

[135] A. N. Srivastva, N. P. Singh and C. K. Shriwastaw, Arab. J. Chem., 9 (2016) 48-61.

[136] A. E. Amra and M.A. Al-Omara, Russ. J. Gen. Chem., 86 (2016) 161-166.

[137] H. A. El-Boraey, M. A. El-Salamony and A.A. Hathout, J. Incl. Phenom. Macrocycl. Chem., 86 (2016) 153-166.

[138] Z. Parsaee and K. Mohammadi, J. Mol. Struct., 1137 (2017) 512-523. 
[139] H. Keypour, M. Mahmoudabadi, A. Shooshtari, L. Hosseinzadeh, F. Mohsenzadeh and R. W. Gable, Polyhedron, 127 (2017) 345-354.

[140] P. Gull, B. A. Babgi and A. A. Hashmi, Microb. Pathogen., 110 (2017) 444-449.

[141] M. Shakir, N. Bano, M. A. Rauf and M. Owais, J. Chem. Sci., 129 (2017) 1905-1920.

[142] K. Soni, R. V. Singh and N. Fahmi, Russ. J. Gen. Chem., 87 (2017) 1610-1617.

[143] M. Shakir, N. Bano, A. Rauf, S. Kazmi and M. Alam, Inorg. Nanomet. Chem., 47 (2017) 576-590.

[144] A. Kumar, V. K. Vashistha, P.Tevatia and R. Singh, Spectrochim. Acta A, 176 (2017) 123133.

[145] M. Bordbar, F. Tavoosi, A. Yeganeh-Faal and M. H. Zebarjadian, J. Mol. Struct., 1152 (2018) 128-136.

[146] H. Keypour, M. Mahmoudabadi, A. Shooshtari, M. Bayat, F. Mohsenzadeh and R. W. Gable, J. Mol. Struct., 1155 (2018) 196-204.

[147] O. A. El-Gammal, A. F. Al-Hossainy and S. A. El-Brashy, J. Mol. Struct., 1165 (2018) 177195.

[148] P. Jain, V. Singh, S. Ali, V. Tripathi and U. Saraswat, J. Saud. Chem. Soc., 22 (2018) 546557.

[149] A. G. B. Dileepan, T. D. Prakash, A. G. Kumar, P. S. Rajam, V. V. Dhayabaran and R. Rajaram, J. Photochem. Photobiol. B: Biology, 183 (2018) 191-200.

[150] J. Liu, Y. Lin, M. Liu, S. Wang, Y. Li, X. Liu and L. Tian, Appl. Organometal. Chem., 33 (2019) 4715 (1-10).

[151] M. Aidi, H. Keypour, A. Shooshtari, M. Bayat, L. Hosseinzadeh, H. A. Rudbari and R. W. Gable, Inorg. Chim. Acta, 490 (2019) 294-302.

[152] S. Ali, V. Singh, P. Jain and V. Tripathi, J. Saud. Chem. Soc., 23 (2019) 52-60.

[153] S. Koçoğlu, H. Ogutcu and Z. Hayval, Res. Chem. Interm., 45 (2019) 2403-2427.

[154] S. Sharma, M. Pimpi, N. Chopra and V. Chugh, Orient. J. Chem., 35 (2019) 318-324. 